Fto 1991 W ENGINEERING DATA TRANSMITTAL

$2 \tan 37,2$

2. To: (Receiving Organization)

Distribution

5. Proj./Prog./Dept./Div.:

Tank. Farm Lightning

Mitigation

3. From: (Originating Organization) Mechanical \& Instrument Sys.

6. Design Authority/ Design Agent/Cog. Engr.:

F. M. Jones

8. Originator Remarks:

This EDT is used to release the Tank Farm Lightning Mitigation TASK PLAN and its APPENDIX which includes the Functional Requirements and Technical Criteria.

11. Receiver Remarks: $\$ 1 A$. Design Baseline Document? [] Yes [X] No

NA

13. Permit/Permit Application No.: NA

14. Required Response Date: $02 / 07 / 97$

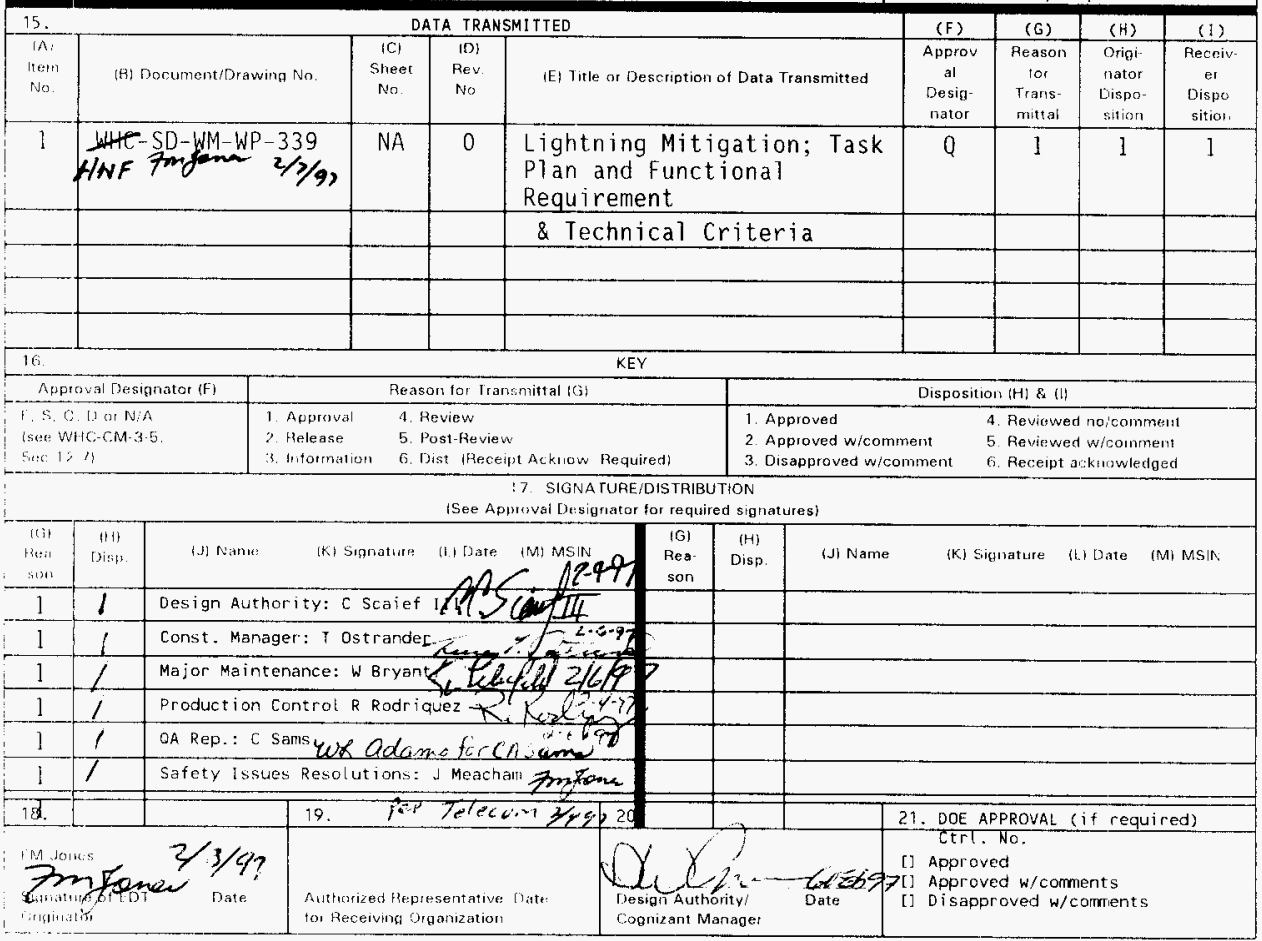

BD-7400-172-2(05/96) GEF097 


\title{
ENGINEERING WORK PLAN TANK FARM LIGHTNING MITIGATION SYSTEM
}

\author{
F. M. Jones
}

Lockheed Martin Hanford Corporation, Richland, WA 99352

U.S. Department of Energy Contract DE-AC06-87Rt-10930-96RL13200 $\mathrm{m}$

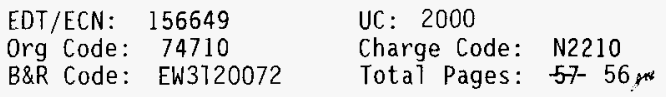

Key Words: Lightning Mitigation, Flammable Gas, Watch List, Single Shell Tarks, Bonding, Air Terminals

Abstract: This Engineering Work Plan defines the scope, function and design criteria, and installation activities that will be provided in support of the Tank Farm Lightning Mitigation System.

The Tank Farm Lightning Mitigation System is comprised of two tasks, the light pole air terminal design and the tank riser bonding design. Air terminals, riser and riser flange bonding system will be designed and installed to mitigate the effect of lightning strikes in single shell tank farms with watchlist tanks.

TRADEMARK DISCLAIMER. Reference herein to any specific commercial product, process, or service by trade name, trademark, manufacturer, or otherwise, does not necessarily constitute or imply its endorsement, recomendation, or favoring by the United States Government or any agency thereof or its contractors or subcontractors.

Printed in the United States of America. To obtain copies of this document, contact: WHC/BCS Document Control services, P.O. Box 1970, Mailstop HG-0B, Richland WA 99352, Phone (509) 372-2420. Fax $(509) 376.4989$.
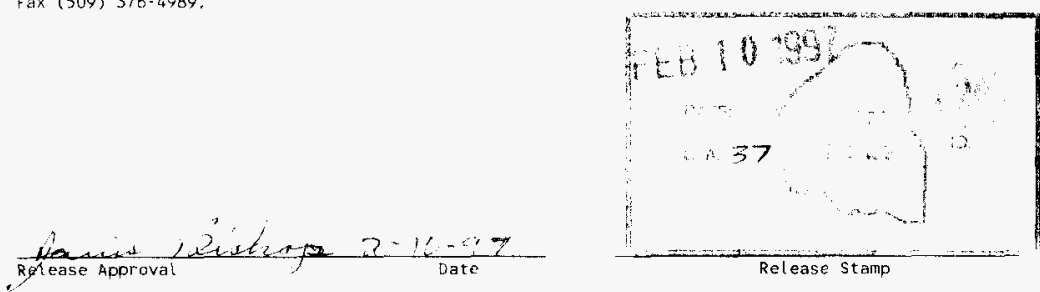

Approved for Public Release 
HNF-SD-WM-WP-339; Rev. 0

ENGINEERING WORK PLAN

TANK FARM LIGHTNING MITIGATING SYSTEM 


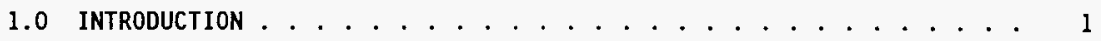

$2.0 \mathrm{SCOPE} \ldots \ldots \ldots \ldots \ldots$

3.0 DESCRIPTION . . . . . . . . . . . . . . . . . . . . 2

3.1 PROGRAM DESCRIPTION . . . . . . . . . . . . . . 2

3.2 DESIGN CRITERIA . . . . . . . . . . . . . . . 2

3.3 CODES AND STANDARDS . . . . . . . . . . . . . . 2

4.0 WORK BREAKDOWN . . . . . . . . . . . . . . 2

4.1 EXISTING LIGHT POLE GROUNDING . . . . . . . . . . . . . . 2

4.2 TANK RISER AND RISER FLANGE BONDING ............ 3

5.0 VERIFICATION ........................ 4

5.1 DESIGN REVIEWS . . . . . . . . . . . . . . . . . 4

5.2 DRAWING CONTROL . . . . . . . . . . . . . . . . . . . 4

5.3 EQUIPMENT CONTROL . . . . . . . . . . . . . . . . . . . . 4

5.4 EQUIPMENT INSPECTION .................. . . 4

5.5 QUALIFICATION TESTING . . . . . . . . . . . . . . 4

6.0 REPORTING REQUIREMENTS . . . . . . . . . . . . . . . 5

7.0 ORGANIZATION . . . . . . . . . . . . . . . . . 5

8.0 SCHEDULE . . . . . . . . . . . . . . . . 5

$9.0 \cos T \ldots \ldots \ldots \ldots$

10.0 PROJECT QUALITY ASSURANCE . . . . . . . . . . . . . 5

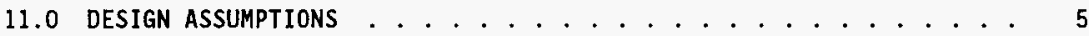

APPENDIX A [Work Plan/Function Criteria] . . . . . . . 7

APPENDIX B [Project Organization] .............. 13

APPENDIX C [Project Schedule] ................. 15

APPENDIX D [Project Cost Estimates] ........... 18

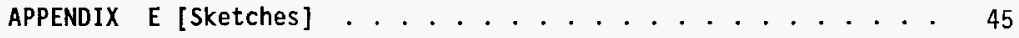




$$
\text { HNF-SD-WM-WP-339; Rev. } 0
$$

\section{LIST OF TERMS}

$A B U$

AIR TERMINAL

AS-BUILT

BOND

CODE

DOWN CONDUCTOR

GROUNDED

NFPA

PERSON IN CHARGE

WALK DOWN
- ACCEPTANCE FOR BENEFICIAL USE

- LIGHTING ROD

- DOCUMENTED FINISHED CONDITION

- ELECTRICALLY CONDUCTIVE PATH

- LAW OR REGULATORY DOCUMENT

- WIRE BETWEEN AIR TERMINAL AND GROUND ROD

- CONNECT TO EARTH

- NATIONAL FIRE PROTECTION ASSOCIATION

(PIC) - OWNER'S REPRESENTATIVE

- VISUAL FIELD INSPECTION 
HNF-SD-WM-WP-339; Rev. 0

\subsection{INTRODUCTION}

This Engineering Work Plan defines the design and installation activities that will be provided in support of the Tank Farm Lightning Mitigation System. Mechanical And Instrument Systems (M\&IS) will assume control for the cost, schedule, technical implementation and installation of this task.

The Tank Farm Lightning Mitigation System is comprised of two tasks, the 1ight pole air terminal design and the tank riser bonding design. Air terminals will be designed and installed to mitigate the effect of 1 ightning strikes in single shell tank farms with watchlist tanks. In addition, Mechanical And Instrument Systems will be responsible for the design and installation for bonding riser flanges and risers.

\subsection{SCOPE}

This document identifies the tasks, schedule, design criteria and organizational responsibilities that Mechanical And Instrument Systems will provide for the lightning mitigation activities. Definitive design activities and associated support efforts included in this planning document will be controlled by the Single Shell Tanks Lightning Hazard Remediation Summary, WHC-SD-WM-ER-604, Revision 0 and Letters of Instructions for Engineering and Design Services.

The objective of this task will be to provide the engineering services necessary to manage detail design and installation for grounding of 1 ight poles and for bonding riser and riser flanges on single shell tanks. These services will include measurements to record resistivity across tank riser flanges and between specified tank risers.

Provide a design with installation instruction for installing lightning protection on forty-three (43) light poles in nine (9) tank farms. Lightning protection will be installed on light poles in 241-A, 241-B, 241-BY, 241-BX, 241-S, 241-SX, 241-TY, 241-TX and 241-U Tank Farms. Detail design for the air terminal is shown on the attached sketches.

Provide a design with installation instruction for bonding at 575 (five hundred and seventy-five) tank risers on fifty-four (54) tanks. Bonding sha 1 be provided on tank risers in 241-A, 241-B, 241-BY, 241-BX, 241-5, 241-SX, 241-TY, 241-TX and 24I-U Tank Farms. Detail designs for the bonding are shown on the attached sketches. 
HNF-SD-WM-WP-339; Rev. 0

\subsection{DESCRIPTION}

\subsection{PROGRAM DESCRIPTION}

Modifications to the light pole grounding and riser flange resistivity are needed to improve lightning mitigation in the single shell tank farms. This task requires modifications of the designated tank farm light poles and tank risers. Air terminals (lightning rods), down conductors and ground rods will be installed on light poles. Bonding links, straps and cables will be installed on risers and riser flanges.

\subsection{DESIGN CRITERIA}

The design criteria for this activity is described in Appendix A; Functional Requirements and Technical criteria document.

\subsection{CODES AND STANDARDS}

Codes, standards, and other documents applicable to this task are listed in Appendix A; Functional Requirements and Technical Criteria.

\subsection{WORK BREAKDOWN}

\subsection{EXISTING LIGHT POLE GROUNDING}

\subsubsection{ENGINEERING TASKS}

This engineering task plan includes guidances for developing definitive design drawings to install air terminals on light poles and locate ground rod placement in nine (9) single shell tank farms and provide installation procedures for definitive job planning.

\subsubsection{INSTALLATION}

Installation of air terminals will require a ground penetrating radar survey prior to the start of trenching and driving ground rods into the earth. Substructures, cable and piping within 10 feet of the area of influence will be conveyed to Mechanical And Instrument systems for addition to the drawings. A walk down in each farm will be conducted to identify hazards, ground level and overhead obstructions. Ground rod to earth resistivity measurements will be recorded to document the final readings. Lock and Tag Procedures will be implemented by Tank Farm Operations before start of air terminal and ground rod installation. LMHC Production Control will be responsible for planning and work package preparation. Major $\mathrm{P}$ lant Maintenance will review designs for constructibility, provide a person in charge (PIC) and craft control for field activities. 
HNF-SD-WM-WP-339; Rev. 0

\subsubsection{DELIVERABLES}

- Detail design drawings that concludes plan views of tank riser locations

- Installation Procedures

- Resistivity measurement procedures

- Resistivity measurement report (Acceptance Report)

- As-Built Drawings

- Approved Acceptance for Beneficial Use (ABU) documentation

\subsection{TANK RISER AND RISER FLANGE BONDING}

\subsubsection{ENGINEERING TASKS}

This engineering task plan includes guidances for developing a definitive design to install bonding straps and riser connection. Installation procedures for definitive job planning will also be required.

\subsubsection{INSTALLATION}

The tank riser and riser flange bonding design will require a ground penetrating radar survey prior to the start of trenching.

Substructures, cable and piping within 10 feet of the area of influence will be conveyed to Mechanical And Instrument Systems for addition to the drawings. A walk down in each farm will be conducted to identify hazards and obstructions. Tank Flange and tank riser resistivity measurements will be recorded to document the final readings. The Lock and Tag Procedure will be implemented by Tank Farm Operations before start of air terminal installation and driving ground rods. LMHC Production Control will be responsible for planning, providing person in charge (PIC) and craft control.

\subsubsection{DELIVERABLES}

- Detail design drawings that concludes plan views of pole locations

- Installation procedures

- Resistivity measurement procedures

- Resistivity measurement report (Acceptance Report)

- As-Built drawings 
HNF-SD-WM-WP-339; Rev. 0

- Approved Acceptance for Beneficial Use (ABU) documentation

\subsection{VERIFICATION}

\subsection{DESIGN REVIEWS}

Mechanical And Instrument Systems will conduct design reviews of facility modifications in accordance with the procedures and requirements of EP 4.1. Design in progress reviews will be informal and as required to assure compliance with cost and schedule. Final design reviews (90\%) for each farm will be conducted per EP 4.1. Mechanica1 And Instrument Systems will have overall responsibility for the designs.

\subsection{DRAWING CONTROL}

Mechanical And Instrument Systems design drawings will be prepared to WHC EP 1.3, EP 1.5, and SDC 1.3. New drawings will be issued as H-14 series drawings, and existing drawings will be modified by ECN. FDNW Design Services will be responsible for design layouts and check of all drawings issued for this task.

\subsection{EQUIPMENT CONTROL}

Mechanical And Instrument Systems has not identified any equipment that requires equipment control. FDNW construction will purchase, store and control all materials and measuring instruments required to accomplish these tasks.

\subsection{EQUIPMENT INSPECTION}

Mechanical And Instrument Systems has not identified any equipment that requires inspection. FDNW construction will provide all materials and measuring instruments required to accomplish these tasks.

\subsection{QUALIFICATION TESTING}

Mechanical And Instrument Systems has not identified any equipment that requires qualification testing. FONW construction will conduct and record resistivity measurements at each light pole, riser and $\mathrm{flange}$ identified in the design. They will also be required to assist in getting the work accepted for beneficial use (ABU). Work packages will be turned over to Tank Farm Operations per the ABU procedure. 
HNF-SD-WM-WP-339; Rev. 0

\subsection{REPORTING REQUIREMENTS}

Mechanical And Instrument Systems will provide weekly status reports to the program manager. Status reports will report on progress by work breakdown; identifying cost and schedule variances and recovery plans for activities within the scope of this planning document. Progress will be reported as a percent complete based on assessments by tasks engineers. Mechanical And Instrument Systems will conduct progress meetings to discuss and resolve issues impacting progress. Meeting minutes documenting decisions commitments, and action items will be distributed to the program manager.

Mechanical And Instrument Systems will obtain the required approval for all project documentation in accordance with WHC procedures EP 1.7. Mechanical And Instrument Systems will include, (as required) Tank Farm Operations, QuaTity Assurance, Safety, and Environmental for the release of $\mathrm{H}-14$ series design drawings and specifications.

\subsection{ORGANIZATION}

Tank Farm Engineering \& Operations are the customer and user. Mechanical And Instrument Systems is responsible for overall project direction. Mechanical And Instrument Systems will be the lead engineering organization for activities described in this document.

\subsection{SCHEDULE}

A detailed project schedule is attached in Appendix C. Mechanical And Instrument Systems will track and status progress to this schedule. FDNW will be responsible for design support services and construction activities as identified by this schedule. Production Control will prepare job packages and planning support. Major Plant Maintenance will provide a PIC to direct FDNW construction forces and LMHC operation and maintenance crafts as identified by the included schedule.

\section{$9.0 \operatorname{CosT}$}

Cost estimates for detail design and construction are attached in Appendix $D$.

\subsection{PROJECT QUALITY ASSURANCE}

Definitive design activities will comply with the requirements specified in documents WHC-CM-4-2 and quality Assurance orders in 10CFR-830.120.

\subsection{DESIGN ASSUMPTIONS}

The installation efforts for the light pole air terminals and bonding task will be initiated no later than January 31, 1997. Start of design later than this date could impact the scheduled September 1, 1997 completion date. 
HNF-SD-WM-WP-339; Rev. 0

The following assumption have been made:

- Expense funding will be provided as required to support definitive design.

- The Functional Requirements and Technical Criteria for this project has been established and will not change.

- Tank Farm Operations will accept bonding cables buried 6 inches below grade.

- Ground penetrating radar scans will be performed per project schedule.

- Construction will maintain red line marked drawings for AS-Built drawings.

- Operations will provide access to tank farm light poles and tank risers per project schedule.

- Obstacles and obstructions will not require undue planning and procedure control to mitigate. 
HNF-SD-WM-WP-339; Rev, 0

APPENDIX A

FUNCTIONAL REQUIREMENT AND TECHNICAL CRITERIA

1.0 SCOOPE

\subsection{PROJECT OVERVIEW}

The Functional Requirement And Technical Criteria for the Tank Farm Lightning Mitigation System is in response to a defense-indepth controls for lightning as an accident initiator identified in the Evaluation of Hazards to Tank Farm Facilities From Lightning Strikes; WHC-SD-WM-SARR-027.

\subsection{DOCUMENT OVERVIEW}

This requirements and criteria document specifically defines performance requirements, technical criteria and deliverables for the light poles grounding and tank riser bonding. The task plan in combination with this document will be used to control the cost and schedule for this task. The basis for the definitive design activities are provided here, in the Single Shell Tanks Lightning Hazard Remediation Summary; WHC-SD-WM-ER-604.

\subsection{APPLICABLE DOCUMENTS}

Codes, standards, and other documents applicable to this program are listed below.

\subsection{DESIGN STANDARDS}

- Installation of Lightning Protection Systems (NFPA 780-1996)

\subsection{GOVERNMENT DOCUMENTS}

- Evaluation of Hazards to Tank Farm Facilities From Lightning Strikes; WHC-SD-WM-SARR-027. 
HNF-SD-WM-WP-339; Rev. 0

- Single-Shell Tanks Riser Resistance to Ground Test Report; WHC-SD-WM-TR-034, Revision 0;

- Single-Shell Tanks Lightning Hazard Remediation Summary; WHC-SD-WM-ER-604, Revision 0;

- Basis for Interm Operation, WHC-SD-WM-BIO-001.

\subsection{PROJECT FUNCTIONS AND REQUIREMENTS}

\subsection{PERFORMANCE CHARACTERISTICS}

Installation of air terminals and tank riser bonding will require ground rods-to-earth and riser-to-riser resistivity measurements. The recorded measurements will serve as the ATP and document the final readings.

\subsubsection{DESIGN REQUIREMENTS}

Modifications to the light pole grounding and tank riser bonding in the tank farm will comply with the standard design provided in Installation of Lightning Protection Systems; NFPA 780-1996.

The lightning protection system shall be designed to capture and arrest lighting strokes that occur in the tank farms. Lightning protection equipment that protrudes above the existing tank farm equipment shall not interfere with operations and maintenances. Typical sketches are provided in Appendix $E$.

\subsubsection{PHYSICAL CHARACTERISTICS}

The lightning mitigation consists of air terminals with down conductors and not more than two 10 foot ground rods installed on existing light poles in the tank farms. The air terminals and ground rods design shall comply with the requirement in NFPA 780 .

Riser bonding will consist of the installing bonding straps around the flanges. A connection of a grounding cable installed between risers will also be utilized. Additionally there are several other options available (see sketches in the Appendix).

\subsubsection{PROJECT QUALITY FACTOR}

Lightning mitigation is classified "Defense-in-Depth Controls per the Basis for Interm Operation, WHC-SD-WM-BI0-001, Table $5.3 .2 .23 .2-2$ 


\subsubsection{ENVIRONMENTAL CONDITIONS}

The lightning protection systems shall be conventional types, constructed using materials approved for the following Environmental Conditions:

Temperature range:

Humidity range:

Elevation above sea level:

Precipitation:

Wind blown materials:

Wind:

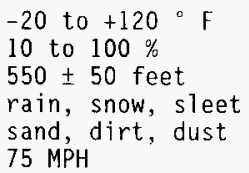

\subsection{DESIGN AND CONSTRUCT}

\subsubsection{MATERIALS}

Standard, commercial materials will be used including air terminals, cables, ground rods, and miscellaneous fasteners.

\subsubsection{WORKMANSHIP}

Standard workmanship is required.

\subsubsection{NAMEPLATES AND PRODUCT MARKINGS}

There are no special requirements for nameplates and product markings. If equipment is UL listed or FM rated, normal cautions should be taken to protect the labelling.

\subsubsection{INTERCHANGEABILITY}

Not applicable.

\subsubsection{SAFETY}

Normal industrial safety practices will be used during installation. The cables will be buried so as to preclude a tripping hazard or a concern that the energy from a lightning strike would present a hazard to personnel working in the farms. 


\subsubsection{HUMAN ENGINEERING}

Since there are few human interactions with the lightning mitigation system, there are few human engineering issues. Once installed, the air terminals are passive.

\subsubsection{NUCLEAR CONTROL}

Since the work is completely external to the tanks, nuclear controls will not be affected.

\subsubsection{SECURITY}

There are no security aspects of the work. The work will be accomplished by individuals who have been cleared for access to the tank farms.

\subsubsection{GOVERNMENT FURNISHED PROPERTY}

The work will be done on the Hanford site in the tank farms, which is a government owned site. The material (air terminals, cabling, ground rods, washers, screws, etc.) will be procured and installed and turned over to the government.

\subsubsection{COMPUTER RESOURCE CAPACITY}

Not Applicable

\subsection{INFORMATION}

Del iverables

The deliverables have been identified in Sections 4.1 .3 and 4.2 .3 of the Engineering Work Plan.

\subsection{LOGISTICS}

Air Terminals

No special requirements. The materials are commercially available, essentially off-the-shelf. The work can be done at any time during daylight, weather permitting. 
HNF-SD-WM-WP-339; Rev. 0

Riser Bonding

Logistics are required. The work has to be coordinated with

Operations to assure that lock $\backslash$ tag procedures $c$ an be done, per the Schedule, weather permitting.

3.6 PERSONNEL AND TRAINING

\subsubsection{PERSONNEL}

Personnel involved in the design and construction will be employees of the Project Hanford companies.

\subsubsection{TRAINING}

The tasks are within the skill-of-the-trade using normal commercial equipment and design. Once the equipment is installed, it is passive. No training for the operators and mechanics is required.

\subsection{CHARACTERISTIC OF SUBORDINATE ELEMENTS}

Not Applicable.

\subsection{PROCEDURE}

Not applicable.

\subsection{QUALIFICATION}

Not applicable.

\subsection{QUALITY ASSURANCE PROVISIONS}

Definitive design activities will comply with the requirements specified in document WHC-CM-4-2 QA Manual.

\section{1 RESPONSIBILITY FOR VERIFICATION}

The PIC will be responsible for resistivity measuring and recording. 


\subsection{SPECIAL TEST AND EXAMINATION}

The materials do not have mechanical or electrical components, no special testing and examination are required for installation.

\subsection{REQUIREMENT CROSS REFERENCE}

Not applicable.

\subsection{PREPARATION FOR DELIVERY}

Since the materials are commercially available and designed for use in the environment, no special preparations are required for delivery.

\subsection{NOTES}

\subsection{INTENDED USE}

The lightning mitigation equipment is being installed to promote the dissipation of lightning energy outside of the waste material stored in the underground single-shell tanks.

\section{1 .1 MISSION}

The mission of the effort is to reduce the probability that a lightning strike in the tank farms can adversely affect the waste stored in the tanks. This system may provide some personnel protection in the farms when lightning occurs.

\section{1 .2 HAZARDS}

There are no hazards associated with the installation of the equipment affecting the tank waste. Normal construction techniques will be used. 
HNF-SD-WM-WP-339; Rev. 0

APPENDIX B PROJECT ORGANIZATION 

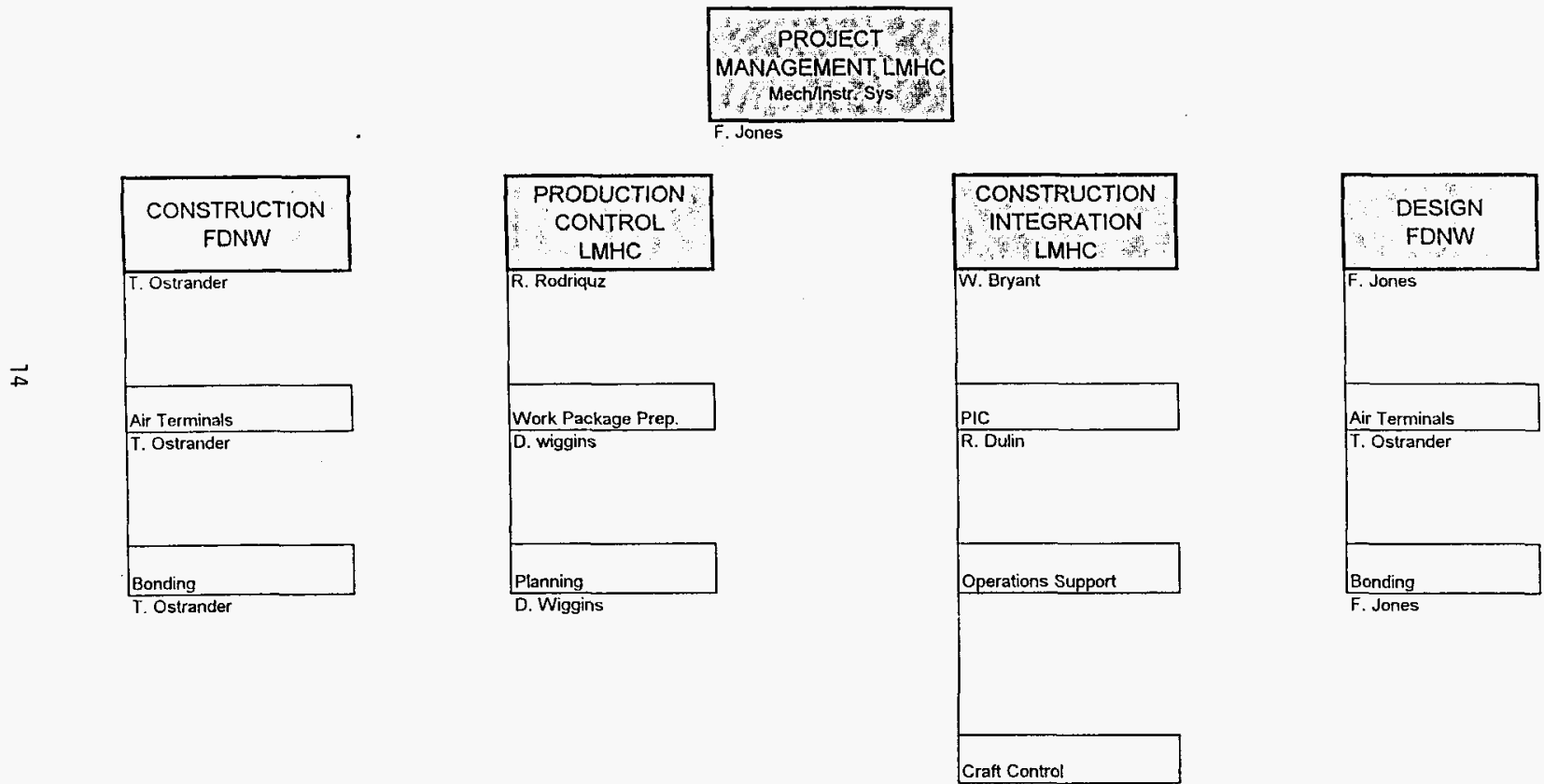
HNF-SD-WM-WP-339; Rev. 0

APPENDIX C PROJECT SCHEDULE 


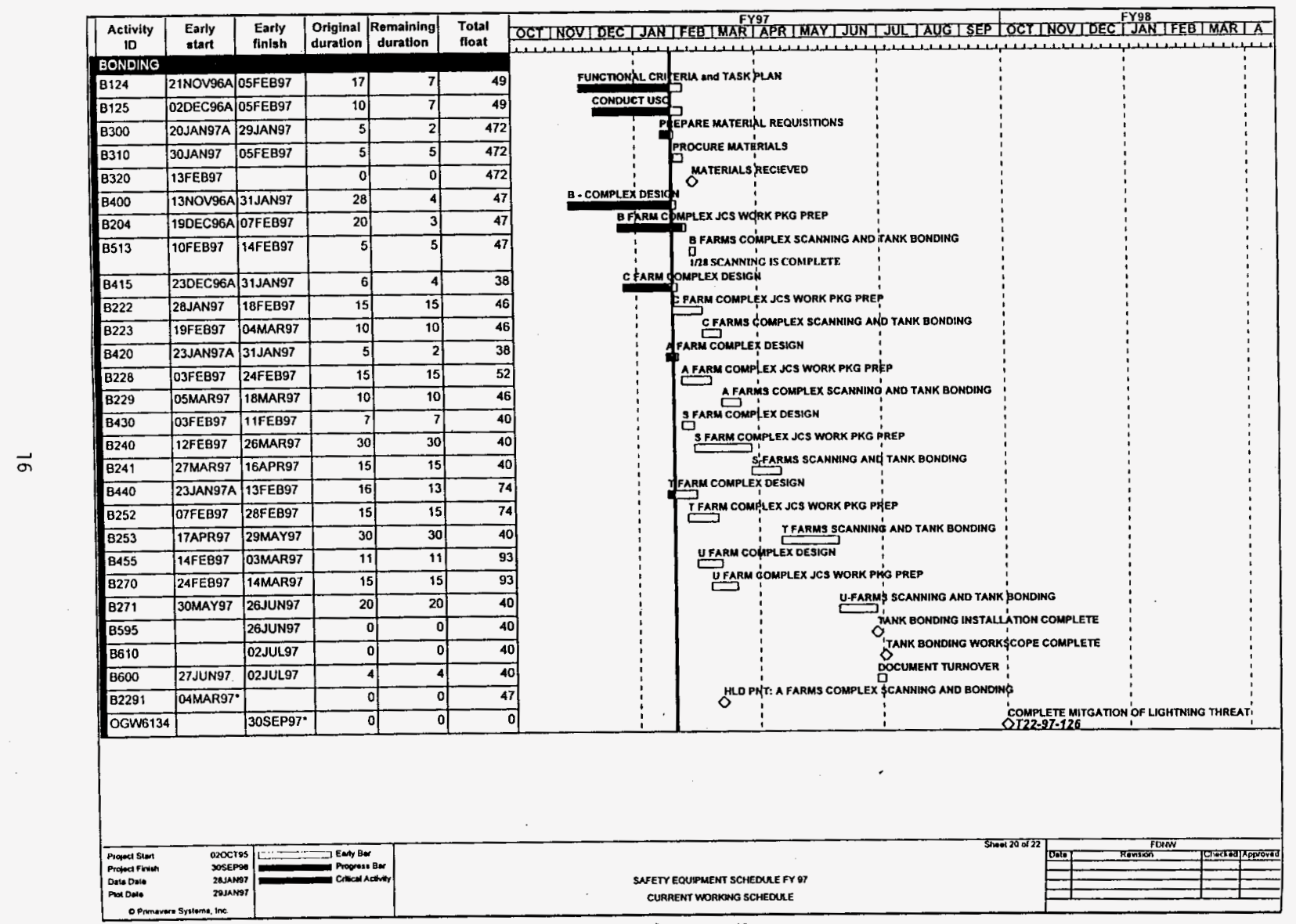




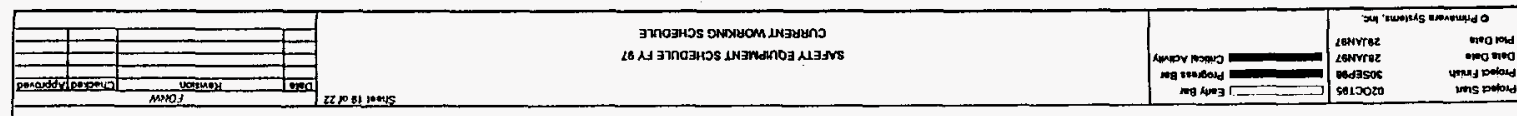

313า

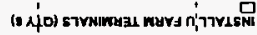
!

Mros onnoys maYy in myosygd

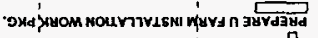

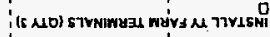

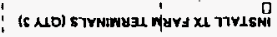

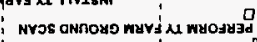

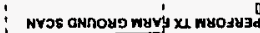

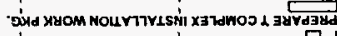

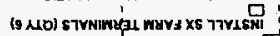

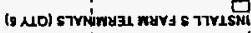
nvos axnoyo miys xs myosug

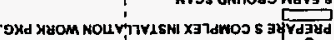

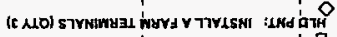

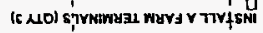

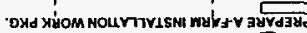

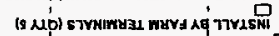
(g)

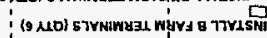
MYOS annoyo nidye Xe wyOay d

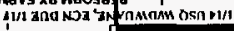

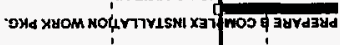

\begin{tabular}{|c|c|c|c|c|c|}
\hline 09 & 0 & 0 & LGNOCEO & & GGSY \\
\hline 09 & 9 & 9 & LENOCHO & $\angle 6 \wedge \vee W B Z$ & S8S \\
\hline $9 \mathrm{RL}$ & $\varepsilon$ & $\varepsilon$ & L683J\&! & 2693ㄴ. & $085 \forall$ \\
\hline 109 & $0 z$ & oz & $\angle 6$ ㅅN & L6บdVGz & $909 \forall$ \\
\hline $2 L$ & 0 & 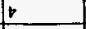 & $\angle 6 \alpha \forall W 80$ & $\angle 6 \times \forall W 50$ & ૬९५ \\
\hline$z 2$ & $t$ & 0 & $\angle 6 \wedge \forall m z O$ & L6ddVGz & SLSY \\
\hline 601 & $E$ & $\varepsilon$ & $\angle 693+01$ & $\angle 68 \exists \pm 90$ & 0 095y \\
\hline 601 & $\varepsilon$ & $\varepsilon$ & $\angle 68 \exists \leq 50$ & L69Jงᄃ0 & $0 \angle S \forall$ \\
\hline 09 & $0 z$ & $0 z$ & LGUdVBz & $\angle 6 \mathrm{UdV} \forall 0$ & tos \\
\hline $6 L$ & 9 & 9 & $\angle 6 \forall d \forall \angle b$ & $\angle 68 d \forall 01$ & ૬૬૬४ \\
\hline 62 & 4 & 2 & LGUdY60 & L68dVLO & Sts \\
\hline$\$ 6$ & $\varepsilon$ & $\varepsilon$ & LENVCIE & $\angle 6 N \forall T 6 Z$ & $055 \forall$ \\
\hline 96 & $v$ & $\varepsilon$ & LENVCIE & $\forall \angle 6 N \forall T L Z$ & Org \\
\hline 09 & 02 & $0 z$ & $\angle 6 \mathrm{~V}$ WIE & $\angle 68 \times W+0$ & $\cos \forall$ \\
\hline 58 & 0 & 10 & &.$\angle 68 \forall 7 \% \angle L$ & ISOSV \\
\hline 98 & $s$ & s & $\angle 6 \forall \forall W L Z$ & L68 $\vee W \angle b$ & $\operatorname{sos} V$ \\
\hline 09 & $0 z$ & loz & $\angle 68 \forall W$ LOO $^{\circ}$ & $\angle 683 \mathrm{JCO}$ & $205 \forall$ \\
\hline$\varepsilon 6$ & $L$ & $\leq$ & LGUWW:0 & 6ㅛ칸 & 929Y \\
\hline $\mathrm{E6}$ & 9 & 9 & $\angle 68 \exists+1 z$ & $\angle 6835 \varepsilon 1$ & SESY \\
\hline \multirow[t]{2}{*}{ E6 } & 8 & $\theta$ & L68 $3 J Z L$ & $\angle 6 \mathrm{~g} 3 \mathrm{~J} \mathrm{CO}$ & SISY \\
\hline & 0 & 5 & $\forall \angle 6 N \forall T^{\circ} Z$ & $\forall \angle 6 N V I L$ & oEs \\
\hline 09 & I & $0 z$ & $\angle 6 !$ & V9GAONIZ & Los \\
\hline & & & & \multicolumn{2}{|c|}{ S7ษNmy 1 yiv } \\
\hline $\begin{array}{l}\text { peov } \\
\text { 12101 }\end{array}$ & 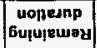 & $\begin{array}{l}\text { uopennp } \\
\text { leuj6po }\end{array}$ & $\begin{array}{l}\text { 4श्ü } \\
\text { אןJez }\end{array}$ & 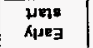 & 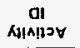 \\
\hline
\end{tabular}


HNF-SD-WM-WP-339; Rev. 0

APPENDIX D PROJECT COST ESTIMATES 
HNF-SD-WM-WP-339; Rev. 0

ICF KAISER HARFORD

WESTI HGHOUSE HANFORO COMPAHY

JOB NO. E23494/FGEBL4

FILE NO. Y978SAA1
* IEST - IHTERACTIVE ESTIHATING **

LIGHTHING HIT IGATION

DOE_RO1 PTUDY (ROH)
PAGE 1 OF 7

DATE 05/01/96 11:26:25

BY DEA

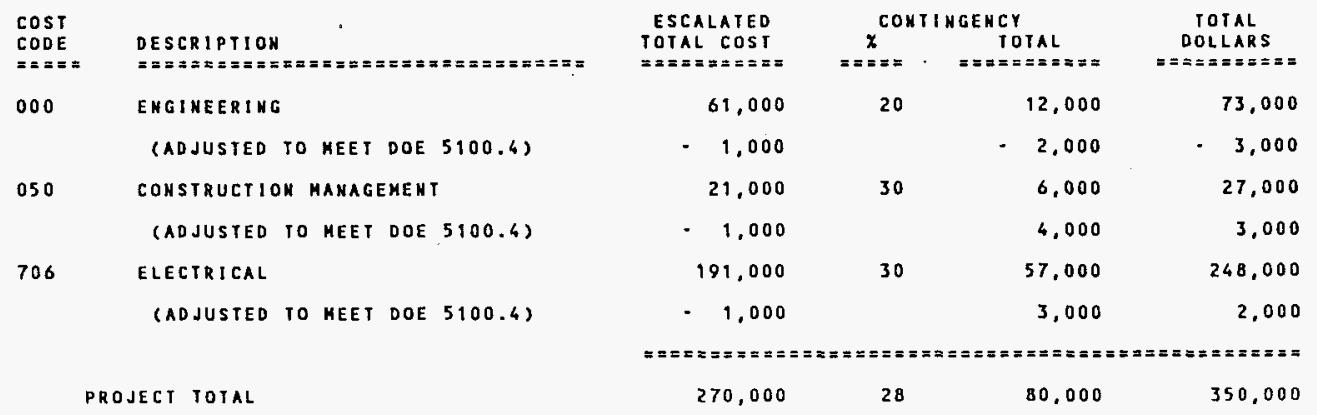

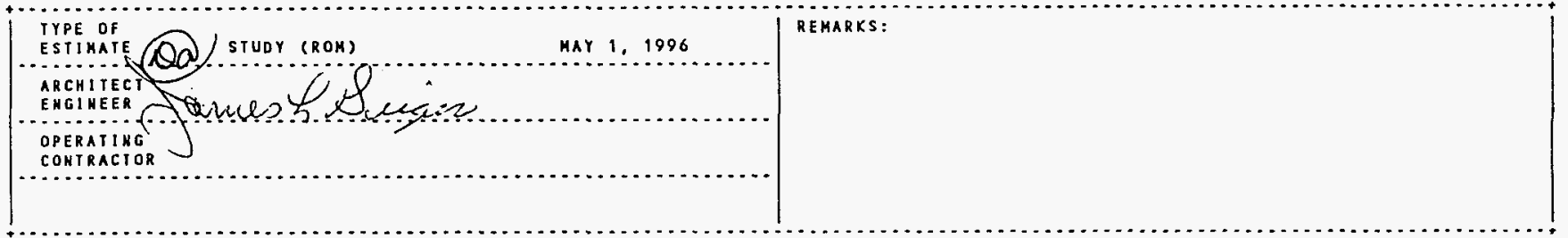

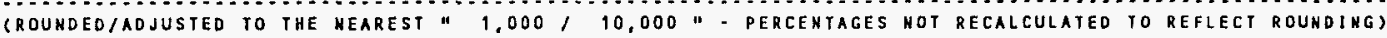

Page 19 
HNF-SD-WM-WP-339; Rev. 0

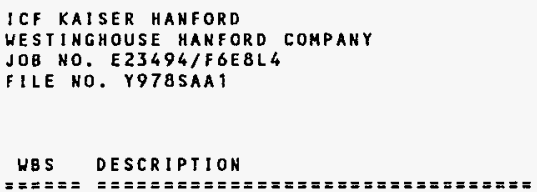

PROJECT TOTAL

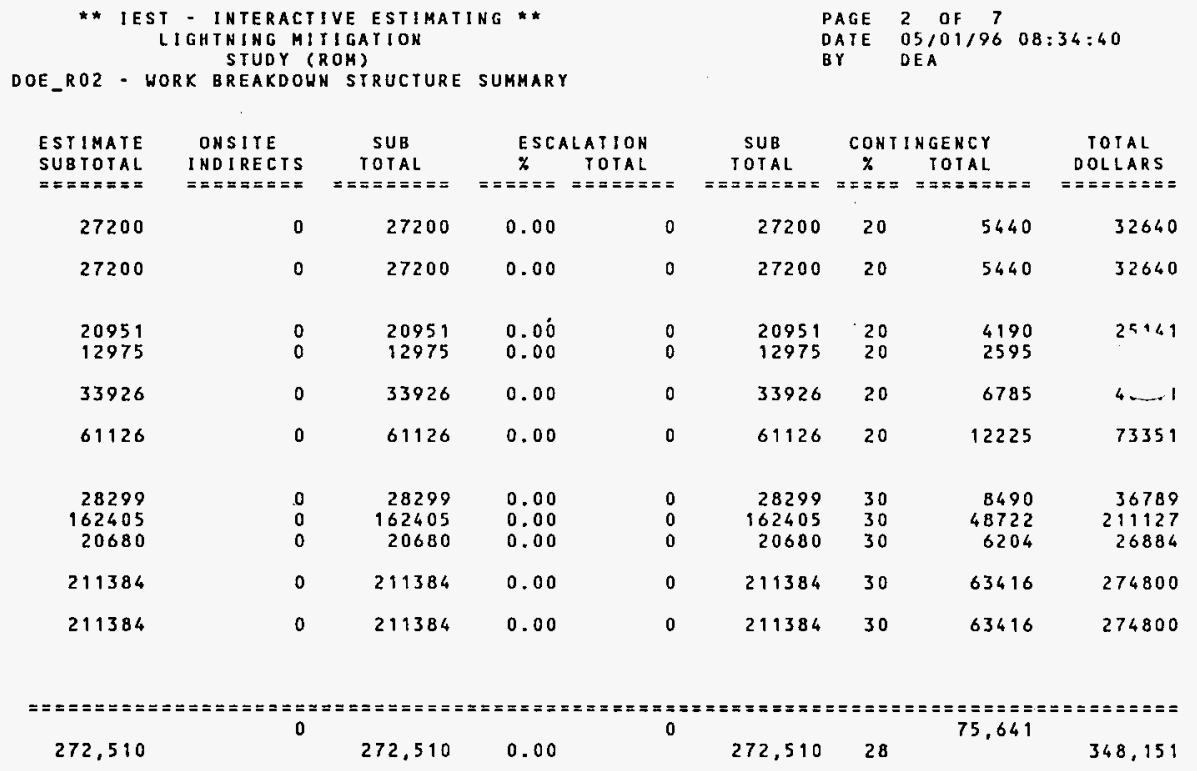


ICF KAISER HANFORD

WESTINGHOUSE HANFORD COMPANY

JOB NO. E23494/F6EBL4

F1LE NO. Y978SAAI
* IEST - INTERACTIVE ESTIMATING **
LIGHTNING MITIGATION
STUDY (ROM)
DOE_RO3 - ESTIMATE BASIS SHEET

PAGE 3 OF $?$

DAIE 05/01/96 15:21:39

BY

1. DOCUMENIS AND DRAWINGS

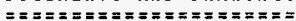

DOCUMENTS: WORK SCOPE DESCRIPTIOH PROVIDED BY JIM ZACH/HHC; ANO CATALOG CUT SHEETS FOR INSIALLATION MATERIAL.

DRAHINGS: SKETCH - AIR TERMINAL MOUNTED ON WOOD POLE DETAILS

SKETCH - GROUNO GRID INSTALLATION DETAILS

2. MATERIAL PRICES

$=============$

UNIT COSTS REPRESENT CURREHT PRICES FOR SPECIFIEO MATERIAL. VENDOR INFORMATION HAS OBTAINED FOR THE FOLLOHING ITEMS: PRICING FOR LIGHTNING PROTECION MATERIAL QUOTED BY GEM ELECIRICAL SALES AT (206) $763-4010$.

3. LABOR RATES

A.) ICF $==$ KH HOURLY RATES ARE BASED ON THE 1996 FISCAL YEAR BUDCET LIOUIDATIOH RATES AS ISSUED BY KEH FINANCE (EFFECTIVE 03-11-96). SEE ALSO THE FY 1995 PLANHING RATES * (REPORT 8 GHB7012).

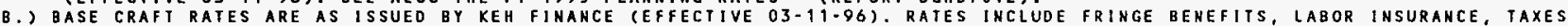

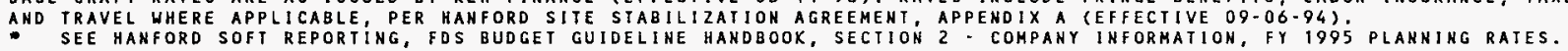

4. GENERAL REQUIREMENTS/TECHNICAL SERVICES/OVERHEADS

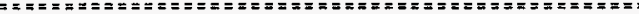

A.) ONSITE CONSTRUCIION FORCES GENERAL REQUIREMENTS, TECHNICAL SERVICES AND CRAFT DVERHEAD COSTS ARE INCLUDED AS A

COMPOSITE PERCENTAGE BASED ON THE ICF-KH ESTIMAIING FACTOR, REVISION 1, FY96, DATED O3/OB/96. THE TOTAL COMPOSITE

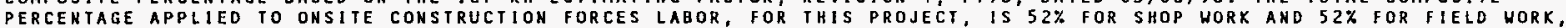
HHICH IS REFLECTEO IN THE "OHEP/B\&I" COLUMN OF IHE ESTIMATE DETAIL.

5. ESCALATIOH

$======\equiv=$

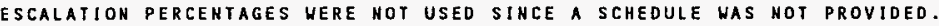

6. ROUNDING

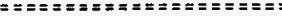

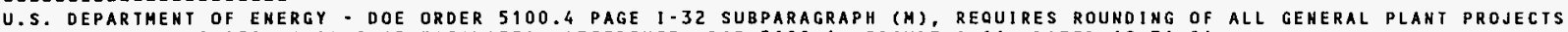
(GPP'S) AND LINE ITEM (L1) COST ESTIMATES. REFERENCE: DOE 5100.4, FIGURE I-11, DATED 10-31-84.

7. REMARKS

$==\equiv= \pm==$

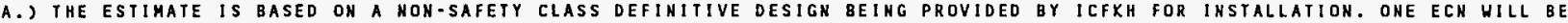

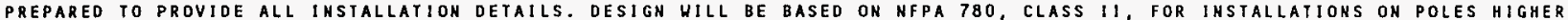
YHAH 75F IALL. THIS EFFORT HILL NOT INCLUDE UPDATING ANY AFFECTED ORAWINGS

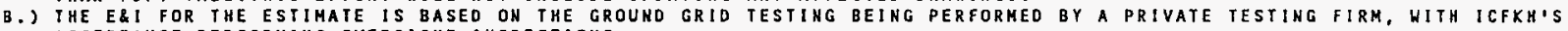
ACCEPTANCE PERFORMING OVERSIGHT INSPECTIONS.

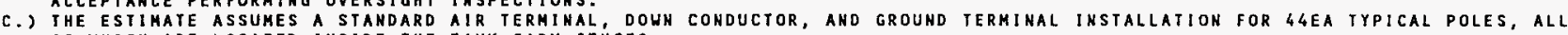
OF WHICH ARE LOCATED INSIDE THE TANK FARM FENCES.

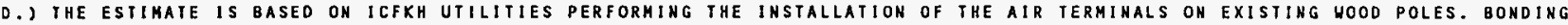
TO EXISIING METAL AND FIXTURES IS INCLUDED.

E, THE ESTIMATE IS BASED OH ICFKH CONSTRUCTION FORCES INSTALLING THE GROUND GRID.

F.) THE ESTIMAIE DOES NOT INCLUDE THE HANDLING OR DISPOSAL OF HAZARDOUS/CONTAKINATED MATERIALS.

G.) THE ESTIMAIE DOES NOT IHCLUDE ANY WHC PROJECT MANAGEMENT, INTEGRATION, OR OTHER PROJECT COSTS. 
HNF-SD-WM-WP-339; Rev. 0

ICF KAISER HANFORD

WESTINGHOUSE HANFORD COMPANY

JOB NO. E23494/F6E8L

FILE NO. YOTBSAA1

$\cos T$

CODE / HBS

OESCRIPTI ION

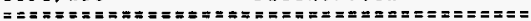

\section{OOO ENGINEERIHG}

110000 DEFINITIVE DESIGN

121000 ENGINEERING

122000 INSPECTION

TOTAL 000 ENGINEERING

050 CONSTRUCIION MANAGEMENT

317720 CF SUPPORI

TOTAL 050 CONSTRUCTION MANAGEMENT

706 ELECTR:CAL.

310001 ICFKH UTILITIES

310002 ICFKH CONSTRUCTION FORCES

TOIAL 706 ELECTRICAL

PROJECT TOTAL

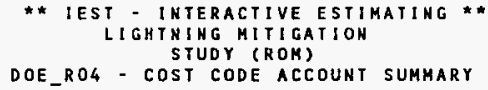

** IEST - INTERACTIVE ESTIMATING * *

LIGHTNING MITIGATIOH

STUDY (ROM)

DOE_ROG - COST CODE ACCOUNT SUMMARY

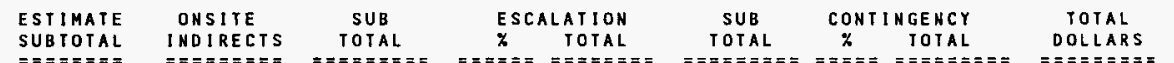

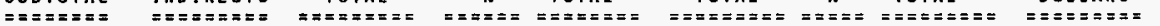

PAGE 4 OF 7

DAIE $05 / 01 / 96 \quad 08: 34: 43$

BY DEA

$\begin{array}{lllllllll}27200 & 0 & 27200 & 0.00 & 0 & 27200 & 20 & 5440 & 32640 \\ 20951 & 0 & 20951 & 0.00 & 0 & 20951 & 20 & 4190 & 25141 \\ 12975 & 0 & 12975 & 0.00 & 0 & 12975 & 20 & 2595 & 1 \\ 61126 & 0 & 61126 & 0.00 & 0 & 61126 & 20 & 12225 & \ldots \\ 20680 & 0 & 20680 & 0.00 & 0 & 20680 & 30 & 6204 & 26884 \\ 20680 & 0 & 20680 & 0.00 & 0 & 20680 & 30 & 6204 & 26884\end{array}$

\begin{tabular}{|c|c|c|c|c|c|c|c|c|}
\hline $\begin{array}{r}28299 \\
162405\end{array}$ & $\begin{array}{l}0 \\
0\end{array}$ & $\begin{array}{r}28299 \\
162405\end{array}$ & $\begin{array}{l}0.00 \\
0.00\end{array}$ & $\begin{array}{l}0 \\
0\end{array}$ & $\begin{array}{r}28299 \\
162405\end{array}$ & $\begin{array}{l}30 \\
30\end{array}$ & $\begin{array}{r}8490 \\
48722\end{array}$ & $\begin{array}{r}36789 \\
211127\end{array}$ \\
\hline 190704 & 0 & 190704 & 0.00 & 0 & 190704 & 30 & 57212 & 247916 \\
\hline
\end{tabular}

C.

0

272,510

0.00

0

28

75,641 
HNF-SD-WM-WP-339; Rev. 0

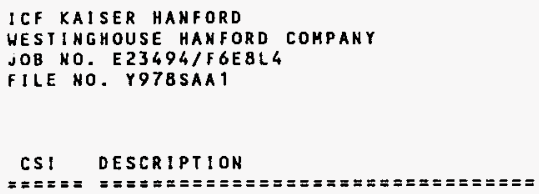

\section{ENGINEERING}

\section{ELECTRICAL \\ 40 PROJECT MANAGER \\ 44 ACCEPINCE INSPECTION}

TOTAL ENGINEERING

\section{CONSTRUCTION}

\section{ELECTRICAL \\ TOTAL CONSTRUCTIOH}

PROJECT TOTAL
* * IEST - INTERACIIVE ESTIMAIIHG * * LIGHTNING MITIGATION

$$
\text { STUDY (ROM) }
$$

DOE_RO5 - ESTIMAIE SUMMARY BY CSI DIVISION
PAGE 5 OF 7

DATE 05/01/96 08:34:44

BY DEA

\begin{tabular}{|c|c|c|c|c|c|}
\hline $\begin{array}{l}\text { STIMATE } \\
\text { UBTOIAL } \\
======\end{array}$ & $\begin{array}{l}\text { ONSITE } \\
\text { INDIRECTS } \\
========\end{array}$ & $\begin{array}{c}\text { SUB } \\
\text { TOIAL } \\
========\end{array}$ & 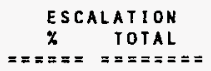 & $\begin{array}{c}\text { SUB } \\
\text { TOIAL } \\
== \pm=====\end{array}$ & 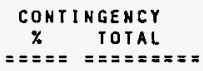 \\
\hline
\end{tabular}

IOTAL $== \pm===$

$===ニ=ニ=$

DOLLARS $== \pm= \pm= \pm$

\begin{tabular}{|c|c|c|c|c|c|c|c|c|}
\hline $\begin{array}{l}37319 \\
10832 \\
12975\end{array}$ & $\begin{array}{l}\text { D } \\
0 \\
0\end{array}$ & $\begin{array}{l}37319 \\
10832 \\
12975\end{array}$ & $\begin{array}{l}0.00 \\
0.00 \\
0.00\end{array}$ & $\begin{array}{l}0 \\
0 \\
0\end{array}$ & $\begin{array}{l}37319 \\
10832 \\
12975\end{array}$ & $\begin{array}{l}20 \\
20 \\
20\end{array}$ & $\begin{array}{l}7464 \\
2166 \\
2595\end{array}$ & $\begin{array}{l}44783 \\
12998 \\
15570\end{array}$ \\
\hline 51,126 & 0 & 61,126 & 0.00 & 0 & 61,126 & 20 & 12,225 & $73, \ldots 1$ \\
\hline 11384 & 0 & 211384 & 0.00 & 0 & 211384 & 30 & 63416 & 274800 \\
\hline 384 & 0 & 211,384 & 0.00 & 0 & 211,384 & 30 & 63,416 & 274,800 \\
\hline
\end{tabular}

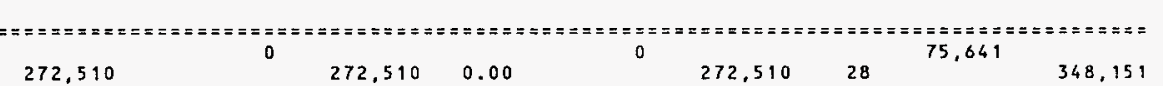

$272,510 \quad 0.00$

272,510

348,151 
HNF-SD-WM-WP-339; Rev. 0

ICF KAISER HANFORD

WEST INGHOUSE HAHFORD COMPANY

JOB HO. E $23494 / F 6 E B L 4$

FILE NO. YQTBSAA1
* IEST * IHTERACTIVE ESTIMATING * *

LIGHTHING MIYIGATION

STUDY (ROM)

DOE_ROG - CONTINGENCY AHALYSIS BASIS SHEET
PAGE 6 OF 7

DATE 05/01/96 15:21:54

BY DEA

REFERENCE

ESTIHATE BASIS SHEET

IHE U.S. DEPARTMENT OF ENERGY - RICHLAND ORDER 5700.3 "COST ESTIMATIMG, ANALYSIS AND STANDARDIZATION" DATED 3-27-85; PROVIDES GUIDELINES FOR ESTIMATE CONTINGENCIES. IHE GUIDELIHE FOR A GSTUDY G ESTIMATE $S H O U L D$ HAVE AH OVERALL RANGE OF 20 TO 30 .

CONIIHGENCY IS EVALUATED AT THE THIRD COST CODE LEVEL AND SUMMARIZED AT THE PRIMARY AND SECONDARY COSY CODE LEVEL OF THE DETAILED COST ESTIMATE.

\section{ENGINEERING}

$000110000 / 121000 / 122000$

A TWENTY PERCENT CONTINGENCY BASED ON THE LEVEL

OF IHFORMATION DEFIHING THE DESIGN REQUIREMENTS

AND POSSIBLE CHANGES DUE TO UNFORSEEN FIELD

CONDIIIONS.

AVERAGE ENGINEERING CONTINGENCY

CONSTRUCTION

050317720

$706310001 / 310002$

A THIRTY PERCENT CONTINGENCY IS BASED ON THE LEVEL

OF DESIGN AND POSSIBLE UNFORSEEN CONSTRUCIION

I MPACTS

AVERAGE CONSTRUCIION CONTIHGENCY

$30 \%$

AVERAGE PROJECT CONTINGENCY 
HNF-SD-WM-WP-339; Rev. 0

* iest * Interactive estimating * LIGHTHING MITIGATIOH STUDY ( $R O M$ )

\section{CF KAISER HAHFORD}

HESTINGHOUSE HANFORD COMPANY

JOB NO. E23494/F6E8L 4

FILE NO. Y978SAA1

* iest - interactive estimating *

LIGHTHING MITIGATION

STUDY (ROM)

HBS DESCRIPIION

W:

110000 DEFINITIVE DESIGH

121000 ENGINEERIHG

122000 INSPECTION

310001 ICFKH UTILITIES

310002 ICFKH CONSTRUCIION FORCES

317720 CF SUPPORT

PROJECT TOIAL
DOE_RO7 - ONSITE INDIRECT COSTS BY WBS

ESTIMAT
SUBTOTA
$======$

2720
2095
1297
2829
16240
2068

CONTRACT ADMINISTRAIION

$\mathbf{X}$

IOTAL
$==\pi=\pi= \pm=\pi$

0
0
0
0
0
0

0.00

0.00
PAGE 1

DATE $05 / 01 / 96 \quad 08: 34: 49$

BY
PAGE 7 OF 7

DATE 05/01/96 08:34:46

BY DEA

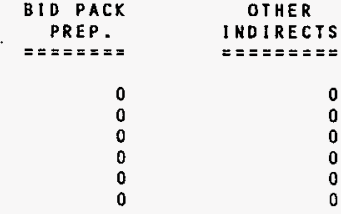

TOTAL INDIRECIS $=\overline{=}=\overline{=}=\overline{=}$

\section{0}

$\begin{array}{lllll}0.00 & 0 & 0 & 0 \\ 0.00 & 0 & 0 & 0 & 0 \\ 0.00 & 0 & 0 & 0\end{array}$

$\begin{array}{lllll}0.00 & 0 & 0 & 0 & 0\end{array}$

0

0

0 
ICF KAISER HANFORD

WESTINGHOUSE HANFORO COMPANY

JOB HO. E23494/F6EBL 4

FILE NO. Y978SAAI

\section{ACCOUNT}

HUMBER

OESCRIPTION

121000

ENGINEER ING

121000,3100000 ELECTRICAL ENGINEER - hRITE ECN CHANGES

121000.3100010 EXCAVATIOH PERMITS (1DEA)

121000.3100020 HORK PACXAGE PREPARATION, PLANNING, COOROINATION

TOTAL WBS 121000 EHGINEERING
* IEST - INTERACTIVE ESTIMATING * *

LIGHIHING MITIGATION$$
\text { SIUDY (ROM) }
$$

DOE_ROB - ESTIMATE DETAIL BY HBS / COST CODE

$\cos T$

COOE QUANTITY MAHHOURS LABOR UQUIP

LABOR SUB.

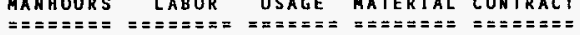

PAGE

BY DEA

\begin{tabular}{|c|c|c|c|c|c|c|c|c|c|c|}
\hline 000 & 16 & MHR & 16 & 1309 & 0 & 0 & 0 & 0 & 0 & 1309 \\
\hline 000 & 200 & MHR & 200 & 16368 & 0 & 0 & 0 & 0 & 0 & 16368 \\
\hline 000 & 40 & MHR & 40 & 3274 & 0 & 0 & 0 & 0 & 0 & $\cdots$ \\
\hline
\end{tabular}


HNF-SD-WM-WP-339; Rev. 0

\begin{tabular}{|c|c|}
\hline $\begin{array}{l}\text { ACCOUNT } \\
\text { NUMBER } \\
== \pm====\approx= \pm=\pi=\end{array}$ & 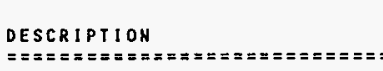 \\
\hline 122000 & INSPECTION \\
\hline $\begin{array}{l}122000.4432000 \\
122000.4432010\end{array}$ & $\begin{array}{l}\text { ELECTRICAL INSPECIOR } \\
\text { GROUND GRID TESTING } \\
\text { BELHAVEN 735-9446 } \\
\text { (2-MEN/DAY D 2-GRIDS/DAY) }\end{array}$ \\
\hline
\end{tabular}

TOIAL HBS 122000 INSPECTION
* IEST * INTERACTIVE ESTIMAIING *

LIGHTNING MITIGATION STUDY (ROM)

DOE_ROB - ESTIMAIE OETAIL BY WBS / COST COOE

EQUIP

CODE QUANTITY MANHOURS LABOR USAGE MATERIAL CONTRACT MUIP- OH\&P I TOTAL

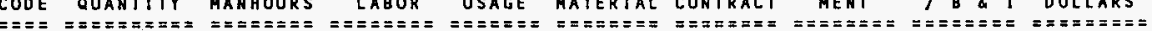

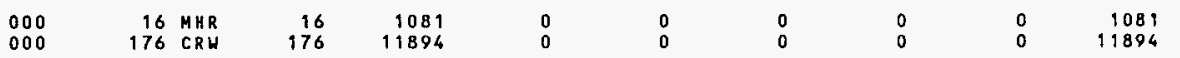

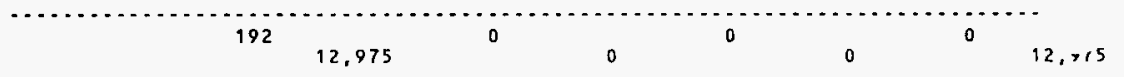

PAGE 3

DATE $05 / 01 / 96 \quad 08: 34: 49$

BY DEA

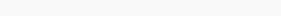


HNF-SD-WM-WP-339; Rev. 0

ICF KAISER HANFORD

WESTINGHOUSE HANFORD COMPANY

JOB NO. E 406B1/FBHO4F

FILE NO. YAOTSAAI
* IEST - INTERACTIVE ESTIMATING * *

LIGHTNING PROTECTOH - TANK RISER BONDING ROUGH ORDER OF MAGNITUDE

DOE ROI - PROJECT COST SUMMARY
PAGE 1 OF 10

DATE $08 / 13 / 96 \quad 14: 34: 31$

BY DEA

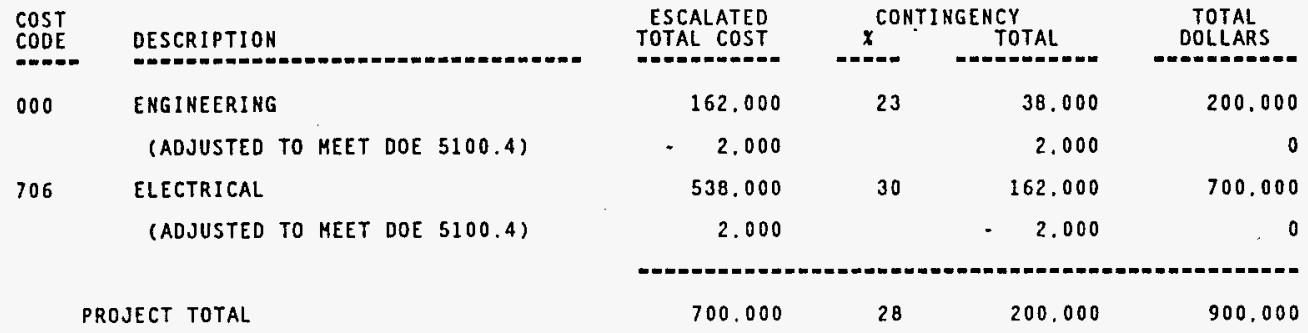

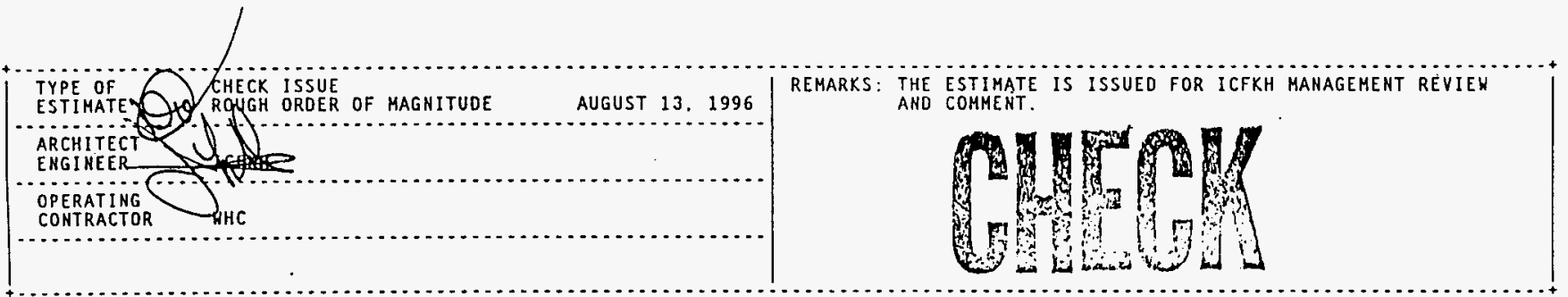

(ROUNDED/ADJUSTED TO THE MEAREST * $1.000 / 10.000^{\circ}$ - PERCENTAGES NOT RECALCULATED TO REFLECT ROUNDING) 
HNF-SD-WM-WP-339; Rev. 0

ICF KAISER HANFORD

WESTINGHOUSE HANFORD COMPANY

JOB NO. E4O6BI/FBHOAF

FILE NO, YAOTSAAI

HES DESCRIPTION

110000 DEFINITIVE DESIGN

SUBTOTAL 11 DEFINITIVE DESIGN

120000 ENGINEERING/INSPECTION

SUBTOTAL 12 ENGINEERING/INSPECTION

SUBTOTAL 1 ENGINEERING

310001 TANK A-101

310002 TANK A-103

310003 TANK AX-101

310004 TANK AX-102

310005 TANK AX-103

310006 TANK $B-103$

310007 TANK B-201

310008 TANK $B-202$

310009 TANK $B X-107$

310010 TANK $B X-110$

310011 TANK BY-101

310012 TANK 8Y=102

310013 TANK BY-103

310014 TANX BY-105

310015 TANK BY-106

310016 TANK BY-109

310017 TANK $\mathrm{C}=102$

310018 TANK $\mathrm{C}=103$

310019 TANK $C=104$

310020 TANK $\mathrm{C} \cdot 107$

310021 TANK $S \cdot 101$

310022 TANK S-102

$5-103$

310024 TANK $5-105$

310025 TANK S-106

310026 TANK $5-107$

310027 TANK $5-109$

310028 TANK $S-111$
* * IEST - INTERACTIVE ESTIMATING * *

LIGHTHING PROTECTON - TANK RISER BONDING ROUGH ORDER OF MAGNITUDE

DOE_RO2 - WORK BREAKDOWN STRUCTURE SUMMARY
PAGE 2 OF 10

DATE $08 / 13 / 9614: 34: 34$

$8 Y$ DEA

\begin{tabular}{|c|c|c|c|c|c|c|c|c|}
\hline $\begin{array}{l}\text { ESTIMATE } \\
\text { SUBTOTAL }\end{array}$ & $\begin{array}{l}\text { ONSITE } \\
\text { INDIRECTS }\end{array}$ & $\begin{array}{l}\text { SUB } \\
\text { TOTAL }\end{array}$ & ESCA & & $\begin{array}{l}\text { SUB } \\
\text { TDTAL }\end{array}$ & $\mathrm{CONT}$ & CY & $\begin{array}{l}\text { TOTAL } \\
\text { DOLLARS }\end{array}$ \\
\hline 107701 & 0 & 107701 & 0.00 & 0 & 107701 & 20 & 21540 & 129241 \\
\hline 107701 & 0 & 107701 & 0.00 & 0 & 107701 & 20 & 21540 & 129241 \\
\hline 53851 & 0 & 53851 & 0.00 & 0 & 53851 & 30 & 16155 & .70006 \\
\hline 53851 & 0 & 53851 & 0.00 & 0 & 53851 & 30 & 16155 & 16 \\
\hline 161552 & 0 & 161552 & 0.00 & 0 & 161552 & 23 & 37695 & $1,<<47$ \\
\hline $\begin{array}{r}20233 \\
15505 \\
9071 \\
17520 \\
12560 \\
3489 \\
9457 \\
20076 \\
4885 \\
4186 \\
7598 \\
7444 \\
4885 \\
8294 \\
4885 \\
4885 \\
3489 \\
2790 \\
4108 \\
4186 \\
8918 \\
10235 \\
10235 \\
10235 \\
9538 \\
9538 \\
10235 \\
10235 \\
10235\end{array}$ & $\begin{array}{l}0 \\
0 \\
0 \\
0 \\
0 \\
0 \\
0 \\
0 \\
0 \\
0 \\
0 \\
0 \\
0 \\
0 \\
0 \\
0 \\
0 \\
0 \\
0 \\
0 \\
0 \\
0 \\
0 \\
0 \\
0 \\
0 \\
0 \\
0 \\
0\end{array}$ & $\begin{array}{r}20233 \\
15505 \\
9071 \\
17520 \\
12560 \\
3489 \\
9457 \\
20076 \\
4885 \\
4186 \\
7598 \\
7444 \\
4865 \\
8294 \\
4885 \\
4835 \\
3489 \\
2790 \\
4108 \\
4186 \\
8918 \\
10235 \\
10235 \\
10235 \\
9538 \\
9538 \\
10235 \\
10235 \\
10235\end{array}$ & $\begin{array}{l}0.00 \\
0.00 \\
0.00 \\
0.00 \\
0.00 \\
0.00 \\
0.00 \\
0.00 \\
0.00 \\
0.00 \\
0.00 \\
0.00 \\
0.00 \\
0.00 \\
0.00 \\
0.00 \\
0.00 \\
0.00 \\
0.00 \\
0.00 \\
0.00 \\
0.00 \\
0.00 \\
0.00 \\
0.00 \\
0.00 \\
0.00 \\
0.00 \\
0.000\end{array}$ & $\begin{array}{l}0 \\
0 \\
0 \\
0 \\
0 \\
0 \\
0 \\
0 \\
0 \\
0 \\
0 \\
0 \\
0 \\
0 \\
0 \\
0 \\
0 \\
0 \\
0 \\
0 \\
0 \\
0 \\
0 \\
0 \\
0 \\
0 \\
0 \\
0 \\
0\end{array}$ & $\begin{array}{r}20233 \\
15505 \\
9071 \\
17520 \\
12560 \\
3489 \\
9457 \\
20076 \\
4885 \\
4186 \\
7598 \\
7444 \\
4885 \\
8294 \\
4885 \\
4885 \\
3489 \\
2790 \\
4108 \\
4186 \\
8918 \\
10235 \\
10235 \\
10235 \\
9538 \\
9538 \\
10235 \\
10235 \\
10235\end{array}$ & $\begin{array}{l}30 \\
30 \\
30 \\
30 \\
30 \\
30 \\
30 \\
30 \\
30 \\
30 \\
30 \\
30 \\
30 \\
30 \\
30 \\
30 \\
30 \\
30 \\
30 \\
30 \\
30 \\
30 \\
30 \\
30 \\
30 \\
30 \\
30 \\
30 \\
30\end{array}$ & $\begin{array}{r}6070 \\
4652 \\
2721 \\
5256 \\
3768 \\
1047 \\
2837 \\
6023 \\
1466 \\
1256 \\
2279 \\
2233 \\
1466 \\
2488 \\
1466 \\
1466 \\
1047 \\
837 \\
1232 \\
1256 \\
2675 \\
3071 \\
3071 \\
3071 \\
2861 \\
2861 \\
3071 \\
3071 \\
3071\end{array}$ & $\begin{array}{r}26303 \\
20157 \\
11792 \\
22776 \\
16328 \\
4536 \\
12294 \\
26099 \\
6351 \\
5442 \\
9877 \\
9677 \\
6351 \\
10782 \\
6351 \\
6351 \\
-336 \\
-7 \\
.0 \\
5442 \\
11593 \\
13306 \\
13306 \\
13306 \\
12399 \\
12399 \\
13306 \\
13306 \\
13306\end{array}$ \\
\hline
\end{tabular}


HNF-SD-WM-WP-339; Rev. 0

ICF KAISER HANFORD

WESTINGHOUSE HANFORD COMPANY JOB NO. E406B1/F8NO4F

FILE NO YAOTSAAI

HBS DESCRIPTION

310030 TANK $5 x-101$

310031 TANK $5 x-102$

310032 TANK $5 x-103$

310033 TANK $5 x-104$

310034 TANK $5 x-105$

310035 TANK $5 x-106$

310036 TANK $5 \times-109$

310037 TANK $T-110$

310038 TANK T-111

310039 TANK $T-201$

310040 TANK T.202

310041 TANK T.204

310042 TANK TX-102

310043 TANK TX-105

310044 TANK TX-111

310045 TANK TX-112

310046 TANK TX-113

310047 TANK TX-115

310048 TANK TX-118

310049 TANK TY-104

310050 TANK U.102

310051 TANK $U=103$

310052 TANK U-105

310053 TANK U.106

310054 TANK U-107

310055 TANK U-108

310056 TANK $U-109$

310057 TANK $U-111$

310058 TANK $U-203$

310059 TANK $U .204$

SUBTOTAL Ji FA CONST.ONSITE E/C

SUBTOTAL 3 CONSTRUCTION

PROJECT TOTAL
** IEST - INTERACTIVE ESTIMATING ** LIGHTNING PROTECTON . TANK RISER BONDING ROUGH ORDER OF MAGNITUDE

DOE_RO2 - WORK BREAKDOWN STRUCTURE SUMMARY
PAGE 3 OF 10

DATE $08 / 13 / 96 \quad 14: 34: 35$

BY DEA

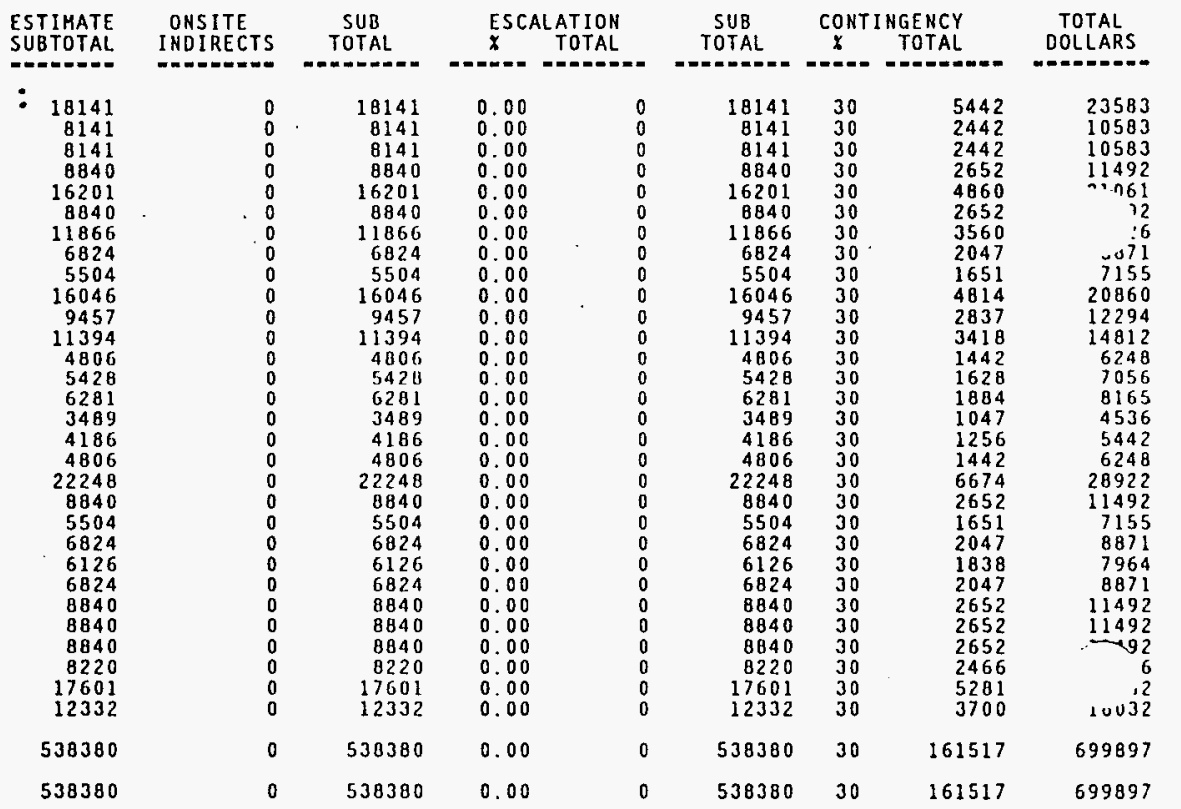

699.932
0.00
599.932
28
199.212

899.144 


\section{ICF KAISER HAHFORD}

WESTINGHOUSE HANFORO COMPANY

JOB NO. E40681/FBNO4F

FILE NO. YAOTSAAI
* * IEST - INTERACTIVE ESTIMATING * *

LIGHTNING PROTECTON . TANK RISER BONDING ROUGH ORDER OF MAGNITUDE

DOE_RO3 - ESTIMATE BASIS SHEET
PAGE 4 OF 10

DATE $08 / 13 / 96 \quad 10: 03: 16$ DEA

1. DOCUMENTS AND ORAWINGS

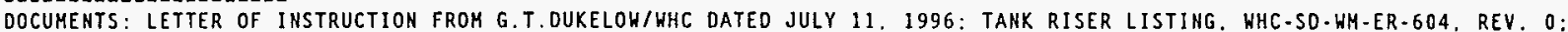
TYPICAL INSTALLATION DETAILS: AND GENERAL TANK FARM SKETCHES.

DRANINGS: HONE.

2. MATERIAL PRICES

UNIT COSTS REPRESENT CURRENT PRICES FOR SPECIFIED MATERIAL.

3. LABOR RATES

A.) ICF-KH HOURLY RATES ARE BASED ON THE 1996 FISCAL YEAR BUDGET LIQUIDATION RATES AS ISSUED BY KEH FINANCE (EFFECTIVE 03-11.96). SEE ALSO THE FY 1996 PLANNING RATES * (REPORT BGHB7012).

B.) BASE CRAFT RATES ARE AS ISSUED BY KEH FINANCE (EFFECTIVE 03-11-96). RATES INCLUDE FRINGE BENEFITS. LABOR INSURANCE. TAXES

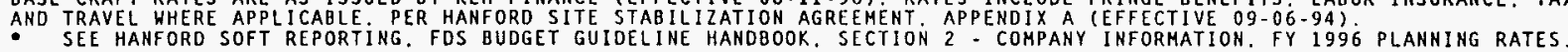

4. GENERAL REQUIREMENTS/TECHNICAL SERVICES/OVERHEADS

A.) ONSITE CONSTRUCTION FORCES GENERAL REOUIREMENTS. TECHNICAL SERVICES AHO CRAFT OVERHEAD COSTS ARE INCLUDED IN THE LOADED

CRAF T WAGE RATE AND THE COMPOSITE PERCENTAGE BASED ON THE ICF.KH ESTIMATING FACTOR. REVISION 1 . FY 95 . DATED $10 / 16 \% 5$. THE

TOTAL COMPOSITE PERCENTAGE APPLIED TO ONSITE CONSTRUCTION FORCES LABOR. FOR THIS PROJECT. IS $52 X$ FOR FIELD WORK. HHICH IS REFLECTEO IN THE OH\&P/BQI- COLUMN OF THE ESTIMATE DETAIL.

5. ESCALATION

AM ESCALATION SCHEOULE HAS NOT PROVIDED AND ON PERCENTAGES WERE APPLIED.

6. ROUNOING

U.5. DEPARTMENT OF ENERGY - DOE ORDER 5100.4 PAGE I- 32 SUBPARAGRAPH (M). REQUIRES ROUNOING OF ALL GENERAL PLANT PROJECTS (GPP'S) AND LINE ITEM (LI) COST ESTIMATES. REFERENCE: DOE 5100.4. FIGURE I-11. DATED 10-31-84.

7. REMARKS

A.) THE ESTIMATE IS BASED ON DEFINITIVE DESIGN BEING PREPARED BY ICFKH ENGINEERING. THE COST IS BASED ON THENTY PERCENT OF THE DIRECT CONSTRUCTION COSTS

B.) THE ESTIMATE IS BASED ON E \& I DURING CONSTRUCTION BEING PERFORMEO BY ICFKH. THE COST IS BASED ON TEN PERCENT OF THE DIRECT CONSTRUCTION COST.

C.) THE ESTIMATE IS BASED ON WORK PERFORMED BY. ICFKH CONSTRUCTION FORCES DURING NORMAL WORKING HOURS.

D.) THE ESTIAMTE DOES NOT INCLUDE THE THE REMOVAL /DISPOSAL COSTS OF ANY HAZARDOUS MATERIALS.

E.) THE ESTIMATE IS BASED ON WHC PROVIDING ALL REQUIRED CONSTRUCTION SUPPORT IN A TIMELY MANNER. 
ICF KAISER HANFORD

WESTINGHOUSE HANFORD COMPANY

JOB NO. E406B1/FBHO4F

FILE NO. YAOTSAAI

$\cos T$

CODE/HBS

DESCRIPTION

OOO ENGINEERING

110000 DEFINITIVE DESIGN

120000 ENGINEERING/INSPECTION

TOTAL OOO ENGINEERING

706 ELECTRICAL

\begin{tabular}{|c|c|c|}
\hline $\begin{array}{l}310001 \\
310002 \\
310003 \\
310004 \\
310005 \\
310006 \\
310007 \\
310008 \\
310009 \\
310010 \\
310011 \\
310012 \\
310013 \\
310014 \\
310015 \\
310016 \\
310017 \\
310018 \\
310019 \\
310020 \\
310021 \\
310022 \\
310023 \\
310024 \\
310025 \\
310026 \\
310027 \\
310028 \\
310029 \\
310030\end{array}$ & $\begin{array}{l}\text { TANK } \\
\text { TANK } \\
\text { TANK } \\
\text { TANK } \\
\text { TANK } \\
\text { TANK } \\
\text { TANK } \\
\text { TANK } \\
\text { TANK } \\
\text { TANK } \\
\text { TANK } \\
\text { TANK } \\
\text { TANK } \\
\text { TANK } \\
\text { TANK } \\
\text { TANK } \\
\text { TANK } \\
\text { TANK } \\
\text { TANK } \\
\text { TANK } \\
\text { TANK } \\
\text { TANK } \\
\text { TANK } \\
\text { TANK } \\
\text { TANK } \\
\text { TANK } \\
\text { TANK } \\
\text { TANK } \\
\text { TANK } \\
\text { TANK }\end{array}$ & $\begin{array}{l}A-101 \\
A-103 \\
A X-101 \\
A X-102 \\
A X-103 \\
B-103 \\
B-201 \\
B-202 \\
B X-107 \\
B X-110 \\
B Y-101 \\
B Y-102 \\
B Y-103 \\
B Y-105 \\
B Y-106 \\
B Y-109 \\
C-102 \\
C-103 \\
C-104 \\
C-107 \\
S-101 \\
S-102 \\
S-103 \\
S-105 \\
S-106 \\
S-107 \\
S-109 \\
S-111 \\
S-112 \\
S X-101\end{array}$ \\
\hline
\end{tabular}

310030
* * IEST - INTERACTIVE ESTIMATING * *

LIGHTNING PROTECTON - TANK RISER BONDING ROUGH ORDER OF MAGNITUDE

DOE_RO4 - COST CODE ACCOUNT SUMMARY
PAGE 5 OF 10

DATE $08 / 13 / 96 \quad 14: 34: 37$

BY DEA
EST IMATE

SUBTOTAL

ONSITE

INQIRECTS

TOTAL

TOTAL
SUB
TOTAL

CONT INGENCY
$\Sigma$ TOTAL
TOTAL DOLLARS

$\begin{array}{rrrrrrrrr}107701 & 0 & 107701 & 0.00 & 0 & 107701 & 20 & 21540 & 129241 \\ 53851 & 0 & 53851 & 0.00 & 0 & 53851 & 30 & 16155 & 70006 \\ 161552 & 0 & 161552 & 0.00 & 0 & 161552 & 23 & 37695 & 7\end{array}$

20233

15505

9071
17520

12560

3489

9457

20076

4885

4186

7598

7444

4865

4885

4885

3489

3489
2790

4108

4186

8918

10235

10235

10235

9538

9538

10235

10235

10235

20233
15505
9071
17520
12560
3489
9457
20076
4885
4186
7598
7444
4885
8294
4885
4885
3489
2790
4108
4186
8918
10235
10235
10235
9538
9538
10235
10235
10235
18141

0.00

0.00

0.00

0.00

0.00

0.00

0.00

0.00
0.00

0.00

0.00

0.00

0.00

o. 00

0.0

0.00

0.00

0.00

0.00

0.00

0.00

0.00

0.00

0.00

0.00

0.00

0.00
0.00
6070

4652

2721

3768

1047

2837

602

6023

1466

1256

2279

2233

1466

2488

1466

1466

1466

1047
837

1232

1256

2675

3071

3071

3071

2861

2861

3071

3071

3071

5442
26303

20157

11792

22776

16328

12294

12294

6351

5442

9877

9677

6351

10782

6351

6351

96
7

.0

5442

11593

13306

13306

13306

12399

12399

13306

13306

13306

23583 
ICF KAISER HANFORD

ORD COMPANY

JOB NO. E40681/FBNO4F

FILE NO. YAO7SAAI

$\cos T$

CODE/H85

DESCRIPTION

310031 TANK $5 X-102$

310032 TANK $5 x-103$

310033 TANK $5 x-104$

310034 TANK $5 x=105$

310035 TANK $5 x-106$

310037 TANK T-110

310038 TANK T-III

310039 TANK T-201

310040 TANK T-202

310041 TANK T.204

310042 TANX TX-102

310043 TANX TX-105

310044 TANK TX-111

310045 TANX TX-112

310046 TANK TX-113

310047 TANK TX-115

310048 TANK TX-118

310049 TANK TY-104

310050 TANK U.102

310051 TANK U.103

310052 TANK $\mathrm{U} .105$

310053 TANK U-106

310054 TANK $\mathrm{U}-107$

310055 TANK $\mathrm{U}-108$

310056 TANK $U-109$

310057 TANK U-111

J1005B TANK U-20J

$\begin{array}{ll}310058 & \text { TANK } U-203 \\ 310059 & \text { TANK } U-204\end{array}$

TOTAL 706 ELECTRICAL

PROJECT TOTAL
* * IEST - INTERACTIVE ESTIMATING **

LIGHTNING PROTECTON - TANK RISER BONDING

ROUGH ORDER OF MAGNITUDE
DOE_RO4-COST CODE ACCOUNT SUMMARY

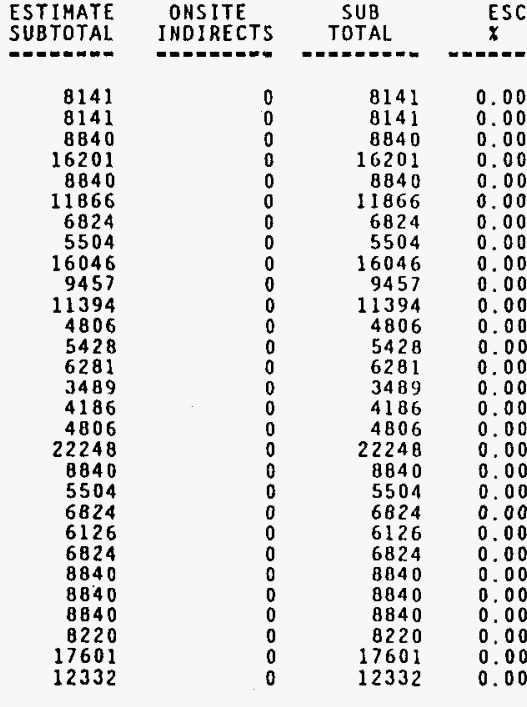

538380
PAGE 6 OF 10

(3:34:38 BY DEA 
HNF-SD-WH-WP-339; Rev. 0

ICF KAISER HANFORD
HESTINGHOUSE HANFORO COMPANY
JOB NO. E $40681 / F 8 N O 4 F$
FILE NO. YAOTSAAI
CSI DESCRIPTION

\section{ENG INEERING}

31 ELECTRICAL

TOTAL ENGINEERING

\section{CONSTRUCTION}

16 ELECTRICAL

TOTAL CONSTRUCTION

PROJECT TOTAL
* IEST - INTERACTIVE ESTIMATING ** LIGHTNING PROTECTON . TANK RISER BONDING ROUGH ORDER OF MAGNITUDE DOE_ROS - ESTIMATE SUMMARY BY CSI DIVISION
PAGE 7 OF 10

DATE $08 / 13 / 96 \quad 14: 34: 40$

BY DEA

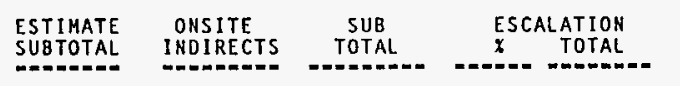

TOTAL
SUB CONTINGENCY TOTAL TOTAL

\begin{tabular}{|c|c|c|c|c|c|c|c|c|}
\hline 161552 & 0 & 161552 & 0.00 & 0 & 161552 & 23 & 37695 & 199247 \\
\hline 161.552 & 0 & 161.552 & 0.00 & 0 & 161.552 & 23 & 37.695 & 1 \\
\hline 538380 & 0 & 538380 & 0.00 & 0 & 538380 & 30 & 161517 & 699897 \\
\hline 538.380 & 0 & 538.380 & 0.00 & 0 & 538.380 & 30 & 161.517 & 699.897 \\
\hline 699.932 & 0 & 699.932 & 0.00 & 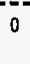 & 699.932 & 28 & 199.212 & 899.144 \\
\hline
\end{tabular}


HNF-SD-WM-WP-339; Rev. 0

ICF KAISER HANFORD

WESTINGHOUSE HANFORD COMPANY

JOB NO. E406B1/FBNO4F

FILE HO. YAO7SAAI

\author{
** IEST - INTERACTIVE ESTIMATING * * \\ LIGHTNING PROTECTON - TANK RISER BONDING \\ ROUGH ORDER OF MAGNITUDE \\ DOE_ROG - CONTINGENCY ANALYSIS BASIS SHEET
}

PAGE $B$ OF 10

DATE $08 / 13 / 96 \quad 10: 03: 32$

BY DEA
REFERENCE : ESTIMATE BASIS SHEET
PAGE
4 OF 10
COST CODE ACCOUNT SUMMARY
PAGE
$\begin{array}{lll}5 & \text { OF } & 10 \\ 6 & \text { OF } & 10\end{array}$

THE US. DEPARTMENT OF EMERGY - RICHLAND ORDER 5700.3 -COST ESTIMATING. ANALYSIS AND STANOARDIZATION" DATED 3.27.85. PROVIDES GUIDELINES FOR ESTIMATE CONTINGENCIES. THE GUIDELINE FOR A 'STUDY' ESTIMATE SHOULO HAVE AN OVERALL RANGE OF 20 TO $30 \%$.

CONTINGENCY IS EVALUATED AT THE THIRD COST CODE LEVEL ANO SUMMARIZED AT THE PRIMARY AND SECONDARY COST CODE LEVEL OF THE DETAILED COST ESTIMATE.

\section{ENGINEERIHG}

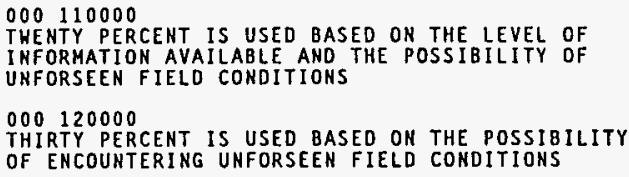

AVERAGE ENGINEERING CONTINGENCY

CONSTRUCTION

$70631 \times X X X$

THIRTY PERCENT IS USED BASED ON THE POSSIBILITY

OF ENCOUNTERING UNFORSEEN FIELD CONDITIONS

AVERAGE CONSTRUCTION CONTINGENCY $30 \%$
AVERAGE PROJECT CONTINGENCY
$28 \%$


HNF-SD-WM-WP-339; ReV. 0

ICF KAISER HANFORD HESTINGHOUSE HANFORD COMPANY JOB NO E40681/F8H04F

FILE NO. YAOTSAAI

HBS

DESCRIPTION

110000 DEFINITIVE DESIGH

120000 ENGINEERING/INSPECTIOH

310001 TANK $A \cdot 101$

310002 TANK A-103

310003 TANK AX-101

310004 TANK AX-102

310005 TANK AX-103

310006 TANK $8-103$

310007 TANK $B-201$

310008 TANK $8-202$

310009 TANK BX-107

310010 TANK $B X+110$

310011 TANK $8 Y-101$

310012 TANK BY-102

310013 TANK BY-103

310014 TANK BY-105

310015 TANK BY-106

310016 TANK - BY-109

310017 TANK $C-102$

310018 TANK $C-103$

310019 TANK $c .104$

310020 TANK $C-107$

310021 TANK 5-101

310022 TANK 5.102

310023 TANK $5=103$

310024 TANK 5-105

310025 TANK S-106

310026 TANK $5-107$

310027 TANK $5-109$

310028 TANK $5-111$

310029 TANK $5-112$

310030 TANK $5 X-101$

310031 TANX $5 X-102$

310032 TANK $5 x-103$

310033 TAHK $5 x-104$

310034 TANK $5 x-105$

310035 TANK $5 X-106$

310036 TANK $5 X-109$

310037 TANK $T-110$

310038 TANK T-111

310039 TANK T-201
* * IEST - INTERACTIVE ESTIMATING * * LIGHTNING PROTECTON - TANK RISER BONDING
ROUGH ORDER OF MAGNITUDE

DOE_RO7 - ONSITE INDIRECT COSTS BY HOS
PAGE 9 OF 10

DATE $08 / 13 / 96 \quad 14: 34: 42$

BY DEA

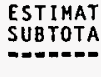

CONTRACT ADMINISTRATION

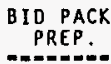

OTHER

INOIRECTS

\begin{tabular}{|c|c|}
\hline $\begin{array}{r}107701 \\
53851 \\
20233 \\
15505 \\
9071 \\
17520 \\
12560 \\
3489 \\
9457 \\
20076 \\
4885 \\
4186 \\
7598 \\
7444 \\
4685 \\
8294 \\
4885 \\
4885 \\
3489 \\
2790 \\
4108 \\
4186 \\
8918 \\
10235 \\
10235 \\
10235 \\
9538 \\
9538 \\
10235 \\
10235 \\
10235 \\
18141 \\
8141 \\
8141 \\
8840 \\
16201 \\
8840 \\
11866 \\
6824 \\
5504 \\
16046\end{array}$ & $\begin{array}{l}0.00 \\
0.00 \\
0.00 \\
0.00 \\
0.00 \\
0.00 \\
0.00 \\
0.00 \\
0.00 \\
0.00 \\
0.00 \\
0.00 \\
0.00 \\
0.00 \\
0.00 \\
0.00 \\
0.00 \\
0.00 \\
0.00 \\
0.00 \\
0.00 \\
0.00 \\
0.00 \\
0.00 \\
0.00 \\
0.00 \\
0.00 \\
0.00 \\
0.00 \\
0.00 \\
0.00 \\
0.00 \\
0.00 \\
0.00 \\
0.00 \\
0.00 \\
0.00 \\
0.00 \\
0.00 \\
0.00 \\
0.00\end{array}$ \\
\hline
\end{tabular}

TOTAL

INOIRECTS 
ICF KAISER HANFORD

WESTINGHOUSE HANFORD COHPANY

JOB NO. E406B1/FBNO4F

FILE NO. YAOTSAAI

HBS

DESCRIPTION

310040 TANK T.202

310041 TANK T.204

310042 TANK TX-102

310043 TANK TX-105

310044 TANK TX-111

310045 TANK TX.112

310046 TANK TX-113

310047 TANK TX-115

310048 TANK TX-118

310049 TANK TY-104

310050 TANK $U-102$

310051 TANK $U-103$

310052 TANK $U-105$

310053 TANK $U-106$

310054 TANK $U .107$

310055 TANK U.108

310056 TANK U-109

310057 TANK U-111

310058 TANK U-203

310059 TANK U-204

PROJECT TOTAL
* * IEST - IHTERACTIVE ESTIMATING * * LIGHTNIHG PROTECTON - TANK RISER BONDING ROUGH ORDER OF MAGNITUDE

DOE_ROT - ONSITE INDIRECT COSTS BY WBS
PAGE 10 OF 10

OATE OB/13/96 14:34:43

BY DEA

$\begin{array}{rc}\text { ESTIMATE } & \text { CONTRACT } \\ \text { SUBTOTAL } & x \\ & \\ 9457 & 0.00 \\ 11394 & 0.00 \\ 4806 & 0.00 \\ 5428 & 0.00 \\ 6281 & 0.00 \\ 3489 & 0.00 \\ 4186 & 0.00 \\ 4806 & 0.00 \\ 22248 & 0.00 \\ 8840 & 0.00 \\ 5504 & 0.00 \\ 6824 & 0.00 \\ 6126 & 0.00 \\ 6824 & 0.00 \\ 8840 & 0.00 \\ 8840 & 0.00 \\ 8840 & 0.00 \\ 8220 & 0.00 \\ 17601 & 0.00 \\ 12332 & 0.00 \\ & \end{array}$

699.932

\section{BID PACK PREP.}

$$
\text { TOTAL }
$$$$
\text { TOTAL }
$$$$
\text { PREP. }
$$

OTHER

INDIRECTS

$$
\begin{aligned}
& 0 \\
& 0 \\
& 0 \\
& 0 \\
& 0 \\
& 0 \\
& 0 \\
& 0 \\
& 0 \\
& 0 \\
& 0 \\
& 0 \\
& 0 \\
& 0 \\
& 0 \\
& 0 \\
& 0 \\
& 0 \\
& 0 \\
& 0
\end{aligned}
$$

0
0
0
0
0
0
0
0
0
0
0
0
0
0
0
0
0
0
0
0

0
0
0
0
0
0
0
0
0
0
0
0
0
0
0
0
0
0
0
0

a

TOTAL I NDIRECTS 
HNF-SD-WM-WP-339; Rev. O

ICF KAISER HANFORO

WESTI INGHOUSE HANFORD COMPANY

JOB NO. E23494/F6E8L 4
* * IEST - INTERACTIVE ESTIMATING * *

LIGHTHING MITIGATION

STUDY (ROM)
PAGE $05 / 01 / 96 \quad 08: 34: 49$ BY DEA
ICF KAISER HANFORD

WESIINGHOUSE HANFORD COMPANY

JOB HO. E23494/FOEQL4

FILE NO. Y97BSAAI

* IEST - INTERACTIVE ESTIMATING * *

LI GHTNIHG MITI GATION

STUOY (ROM)

DOE_RO7 - DNSITE INDIRECT COSTS BY WOS

HBS DESCRIPTION

= = $=$ = =

110000 DEFINITIVE OESIGH

121000 ENGINEERING

122000 INSPECIIDN

310001 ICFKH UTILITIES

310002 ICFKH CONSTRUCTION FORCES

317720 CF SUPPORT

PROJECT TOTAL
ESTIMATE

CONTRACT ADMINISTRATION

$=====\quad$ TOTAL

0.00

0.00

0.00

0.00

0.00

0.00

162405

20680

= = = = = = = = = = = =

272,510
PAGE 7 OF 7

DATE 05/01/96 08:34:46

BY DEA

OIHER
I NOIRECTS
$========$

0
0
0
0
0
0

TOTAL

BID PACK

PREP.

0
0
0
0
0
0

INDIRECTS
$====-==$

0


HNF-SD-WM-WP-339; Rev. 0

ICF KAISER HANFORD

WESTIMGHOUSE HANFORD COMPAHY

JOB HO. E $23494 / F 6 E 8 L 4$

FILE NO. Y978SAA1

\section{ACCOUNT}

NUMBER

DESCRIPIION

121000

ENGINEER ING

121000.3100000 ELECTRICAL ENGINEER

- WRITE ECN changes

121000.3100010 EXCAVATION PERMITS (10EA)

- ENGINEER I HG/PLANNER TIME

121000.3100020 WORK PACKAGE PREPARATION,

PLANNING, COORDINATION

TOTAL WBS 121000 ENGIHEERING
* * IEST - INTERACI IVE ESTIMATING * *

LIGHTNING MITIGATION

STUDY (ROM)

DOE_ROB - ESTIMATE DETAIL BY HBS / COST CODE

$\cos T$

COST
CODE QUANTITY MANHOURS LABOR USAGE

MATER:AL CONTRAC

MANHOURS

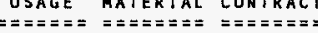

PAGE

DATE $05 / 01 / 96 \quad 08: 34: 49$

BY DEA

EQUIP- OH\&P TOTAL

MENT $\quad B$ \& I DOLLARS

\begin{tabular}{|c|c|c|c|c|c|c|c|c|c|c|}
\hline 000 & 16 & MHR & 16 & 1309 & 0 & 0 & 0 & 0 & 0 & 1309 \\
\hline 000 & 200 & MHR & 200 & 16368 & 0 & 0 & 0 & 0 & 0 & 16368 \\
\hline 000 & 40 & MHR & 40 & 3274 & 0 & 0 & 0 & 0 & 0 & $\cdots$ \\
\hline
\end{tabular}


HNF-SD-WM-WP-339; Rev. 0

ICF KAISER HANFORD
WESTINGHOUSE HANFORD CONPANY
JOB NO. E23 $94 /$ FOE $8 L 4$
FILE NO. Y978SAAI

\section{ACCOUNT}

NUMBER

DESCRIPTION

122000

INSPECTION

122000.4432000 ELECTRICAL INSPECTOR

122000.4432010 GROUND GRID TESTING

BELHAVEN $735-9446$

(2-MEN/DAY O 2-GRIDS/DAY)

TOTAL WBS 122000 INSPECTION
* IEST - INTERACTIVE ESTIMATING **
LIGHTNING MITIGATION
STUDY (ROM)
DOE_ROB - ESTIMATE DETAIL BY WBS, COST CODE
PAGE
DATE 05/01/96 $08: 34: 49$

BY DEA

\section{COST EQUIP SUB- EQUIP- OHEP TOTAL}

CODE QUANTITY MANHOURS LABOR USAGE MATERIAL CONTRACT MENT IB\&I DOLLARS

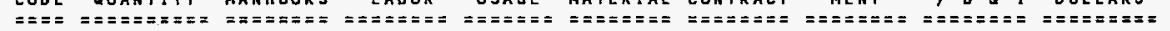

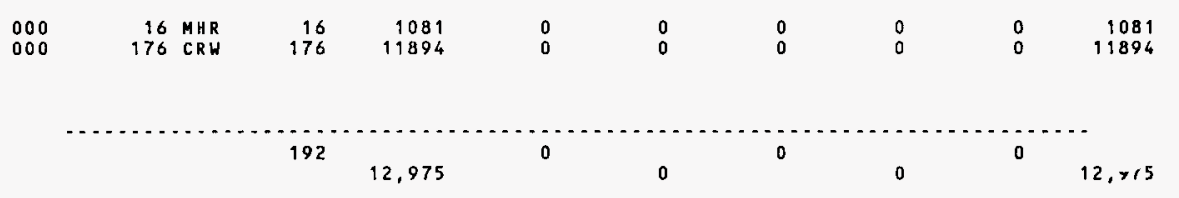




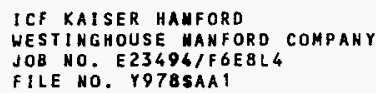

TOTAL

\section{COST CODE 70616}

WBS 310001 (ESCALATION

$0.00 \%$ - CONTINGENCY
* iest - interactive estimating **

$$
\begin{aligned}
& \text { LIGHINING MITIGATION } \\
& \text { STUOY (ROM) }
\end{aligned}
$$

DOE_ROB - ESTIMATE DETAIL SY WBS / COST CODE

COST EQUIP SUB- EQUIP- OH\&P TOTAL

CODE OUANTITY MANHOURS LABOR USAGE MATERIAL CONTRACT MENT I B I DOLLARS

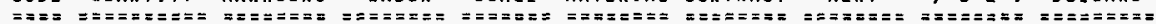

\begin{tabular}{|c|c|c|c|c|c|c|c|c|c|c|}
\hline 706 & 44 & EA & 132 & 6948 & 1560 & 0 & 3300 & 0 & 3613 & 15401 \\
\hline 706 & 44 & EA & 0 & 0 & 0 & 774 & 0 & 0 & 0 & \\
\hline 706 & 88 & EA & 0 & 0 & 0 & 532 & 0 & 0 & 0 & 532 \\
\hline 706 & 44 & EA & 0 & 0 & 0 & 451 & 0 & 0 & 0 & 45 \\
\hline 706 & 44 & EA & 0 & 0 & 0 & 55 & 0 & 0 & 0 & 55 \\
\hline 706 & 300 & EA & 0 & 0 & 0 & 75 & 0 & 0 & 0 & 75 \\
\hline 706 & 2000 & $L F$ & 0 & 0 & 0 & 5700 & 0 & 0 & 0 & 5700 \\
\hline $\begin{array}{l}706 \\
706 \\
706\end{array}$ & $\begin{array}{r}44 \\
1 \\
1\end{array}$ & $\begin{array}{l}\text { EA } \\
\text { LOT } \\
\text { LOT }\end{array}$ & $\begin{array}{l}0 \\
0 \\
0\end{array}$ & $\begin{array}{l}0 \\
0 \\
0\end{array}$ & $\begin{array}{l}0 \\
0 \\
0\end{array}$ & $\begin{array}{l}660 \\
200 \\
500\end{array}$ & $\begin{array}{l}0 \\
0 \\
0\end{array}$ & $\begin{array}{l}0 \\
0 \\
0\end{array}$ & $\begin{array}{l}0 \\
0 \\
0\end{array}$ & $\begin{array}{l}660 \\
200 \\
500\end{array}$ \\
\hline & & & 132 & 6,948 & 1,540 & $\begin{array}{r}8.947 \\
536 \\
758 \\
2655\end{array}$ & 3,300 & $\begin{array}{l}0 \\
0\end{array}$ & 3,613 & $\begin{array}{r}24,348 \\
536 \\
758 \\
2655\end{array}$ \\
\hline & & & 132 & 6.948 & 1,540 & 12,897 & 3,300 & 0 & 3,613 & 28,298 \\
\hline
\end{tabular}

TOTAL WBS 310001 ICFKH UTILITIES $\begin{array}{lrl}\text { PAGE } & 4 & \\ \text { DAIE } & 05 / 01 / 96 & 08: 34: 49\end{array}$ $\begin{array}{ll}\text { DAIE } & 05 / 01 / \\ \text { BY } & \text { DEA }\end{array}$ 
HNF-SD-WM-WP-339; Rev. 0

\section{ICF KAISER HAKFORD}

WESTIHGHOUSE HANF ORO COMPAUY

JOB NO. E23494/F6EBLG

FILE NO. Y97BSAA]

ACCOUNT
NUMBER DESCRIPTION

NUKBER

310002

ICFKH CCNSTRUCT:OH FORCES

310002.16 ELECTRICAL

310002.1644030 GROUND ROO 5i. $X$ J $10 \mathrm{FT}$ THOMPSOH LIGTHIHG PROTECTIOH Ho. TL 5\&10-5i8:XX:OFT

310002.1644032 GROUND ROD CLAMP THOMPSOH LIGTHIHG PROTECTION Ho. 231

310002,1644034 GROUNO ACCESS YELL THOMPSOR LIGENTHG PROTECTION HO. GUP- 1024

310002.1644040 CAB GVP $1 / 0$ CU STRAMDED

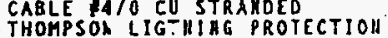
Ho. 507

310002.1644050 HAHD EXCAVAT:OII (1.W X :DX BOFT/POLE) HAMO BACKFILL/COMPACTIOH

SUBTOTAL ELECTRICAL

GEMERAL FORCMAN $7.00 \%$

COKSUMABLES 6.008

SALES TAX B.00\%

WAREHOUS IHG 2 B OO

TOTAL COST CODE 706:6

MQS 310002

(ESCALATION - $0.00 \%$ - CONTIMGENCY $30.00 \%$ )

LIGHTHING NITYGATIOH

DOE_ROB - ESTIMATE DETAIL BY WES I COST CODE

COST EOUIP SUB. EQUIP- OHSP TOTAL

CGDE QUANTITY KANHOURS LABOR USAGE MATERIAL CONTRACT MENT I B I OOLLAR:

C... -

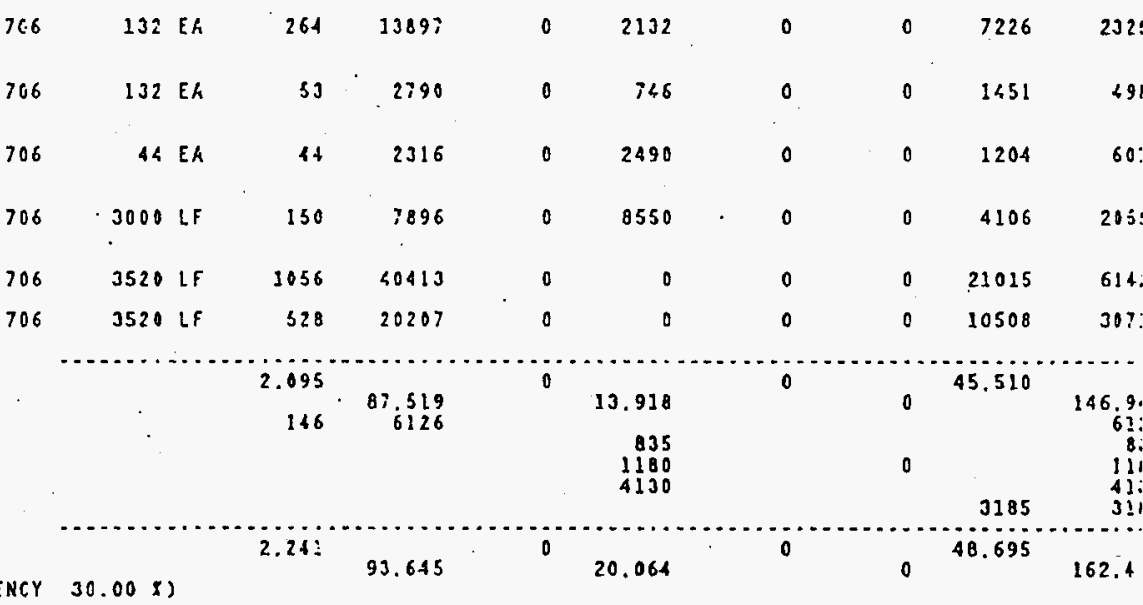

TOTAL WBS 310002 ICFKH COHSTRUCTIOH FORCES
$2.24:$

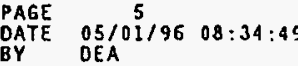

99.645

20.064 
HNF-SD-WM-WP-339; Rev. 0

\section{ICF KAISER HANFORD \\ WESTIMGHOUSE HAHFORD COMPANY \\ JOB KO. E23494/F6E8LA \\ FILE HO. Y97BSAA]}

ACCOUNT

NUHBER

DESCRIPTION

$317720 \quad$ CF SUPPORT

$317720.16 \quad$ ELECTRICAL

317720.1644000 SUB-SURFACE SCANMING SUBTOTAL ELECTRICAL

TOTAL

\section{COST COOE 05016}

WBS 317720

CESCALATIO

$0.00 X$ - COHTIHGEACY

$30.00 \times 1$
* IEST - INTERACIIVE ESTIMATING *" LIGHTHING MITIGATION

DOE ROB - ESTIMATE DETAIL BY WBS / COST COOE
PAGE
DATE : $05 / 01 / 96 \quad 08: 34: 49$
DEA

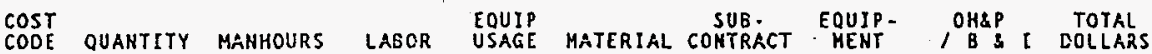
- HENT = -

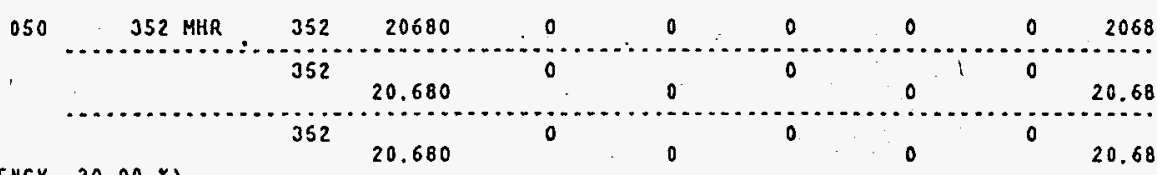

TOTAL WBS 317720 CF SUPPORT

20.680
0

(n)

o

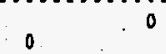

0

20.68 
HNF-SD-WM-WP-339; Rev. 0

ICF KAISER HANFORO

IESTIHGHOUSE HANFORD COMPAHY

JOB NO. E23494/FGEBL4

FILE NO. Y978SAA1

\section{ACCOUNY}

NUMBER

DESCRIPTION

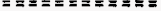

REPORT TOTAL
* * IEST * INTERACTIVE ESTIMATING *

LI GHTHING MITIGAIION

STUDY (ROM)

$\begin{array}{lll}\text { PAGE } & 7 \\ \text { DAIE } & 05 / 01 / 96 & 08: 34: 49\end{array}$

BY DEA

DOE_ROB - ESTIMATE DETAIL BY WBS / COST CODE

EOUIP

CODE QUANTITY MAHHOURS LABOR USAGE

MATERIAL CONTRACT

EQUIP- OH\&P

HENT

TOIAL

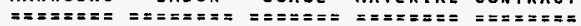

3,493

182,399

1,540

32,962

3,300

0

52,308

272,510 
HNF-SD-WM-WP-339; Rev. 0

APPENDIX E SKETCHES 
HNF-SD-WM-WP-339; Rev. 0

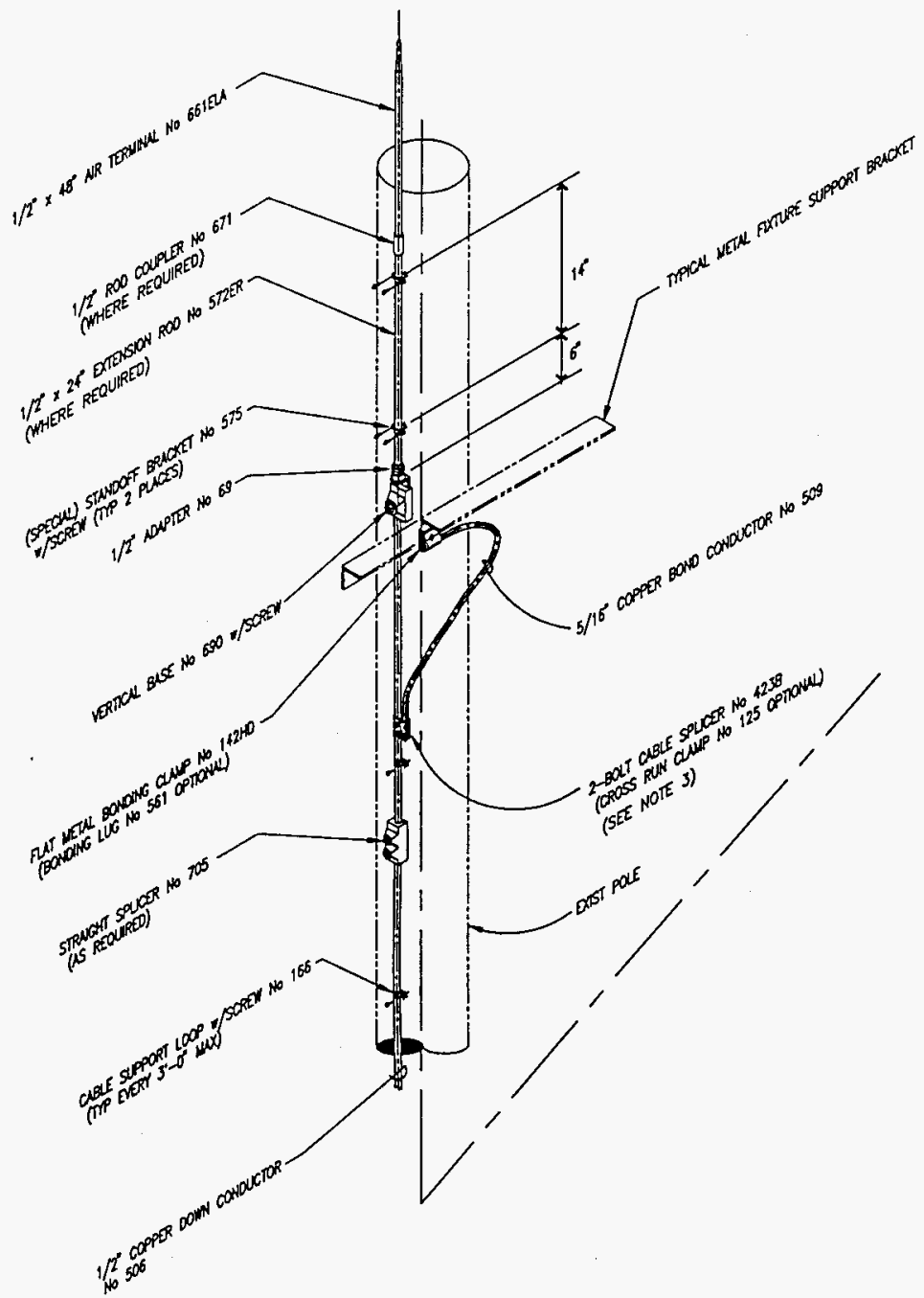

ITEM 1

LIGHTNING PROTECTION TANK

FARM POLES

TYPICAL INSTALLATION DETAILS

SCALE: NONE

(H-14-100875, SH. 2) 


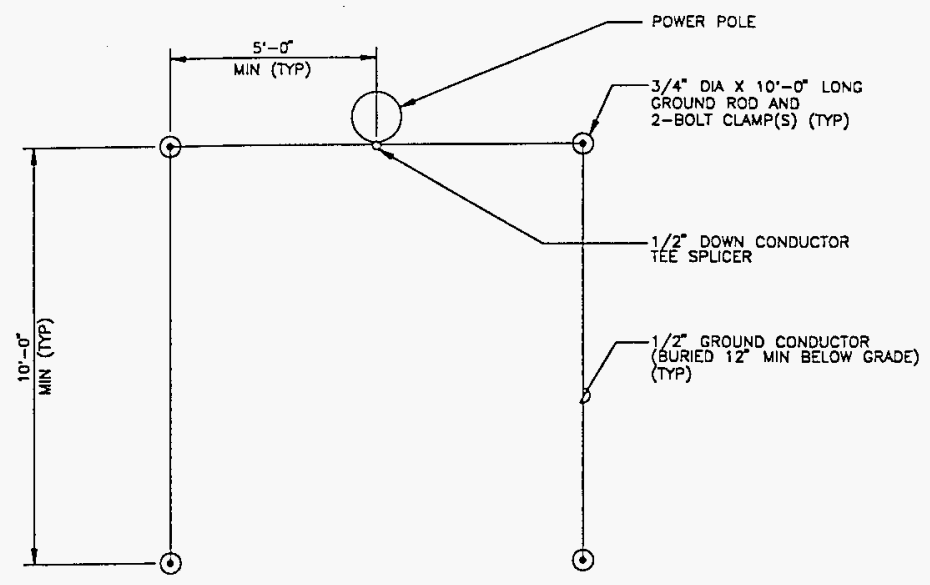

\section{ALTERNATE GROUNDING PLAN EXAMPLE} SCALE: $1 / 2^{\circ}=1^{\circ}-0^{\prime \prime}$ FIELD DETERMINE EXACT ARRANGEMENT

(SEE NOTE 4)

\section{NOTES}

1. CONDUCTOR, NR TERMINL GROUND ROD, HWRDWARE ETC TO BE THOMPSON UGHTNING PROTECTON (CAT No IIP 1993) OR APPROVED EOULL MISCDLANEOUS FASTENERS TO BE SUPPLED BY THE FEE.

2. MNNTNN $2 *-\sigma$ MINBMUM FROM POLF (OR OTHER STRUCTURES) TO GROUND ROD IN ANY DIRECTON WTH $10^{\circ}-\sigma^{\circ}$ MNIMUN BETWEEN RODS.

3. OPTONAL BONDING CONDUCTOR ATTACHMENTS TO THE DOWN CONDUCTOR MAY BE WWOE USING CLAMP NO's 125, $141 \mathrm{X}$ AND 143.

4. SUIVEY FOR UNOERGROUND OBSTRUETIONS. OHNER TO DETERMINE LOCATIONS TO DRME GRDUND RODS. TOP OF GROUND RODS, WHEN FULY DRMEN SHAL BE NO IDSS THAN 1 ' $\sigma$ BEOW GRADE NDO SHUL PENETRATE EARTH AT LEAT $i 1^{\circ}-\sigma^{\circ}$.

5. ACCEPTANCE TESTING REOUIREMENTS.

A) VERIFY CONTINUTY THROUGH $M L$ CONNECTIONS.

A) WESURE NND RECORO GROUND RESISANCE OF INSTAUDD PARAUA GROUND TJRMINULS.

c) PROMDE DOCUMENTATION OF GROUNDING RESISTANCE TESTS. OWNER WILL. DETERMINE IF ANY FURTHER GROUND TERMINAL UPGRADE WORK IS REQUIRED.

ITEM 2

LIGHTNING PROTECTION TANK FARM POLES TYPICAL INSTALLATION DETAILS

(H-14-100875, SH. 2) 

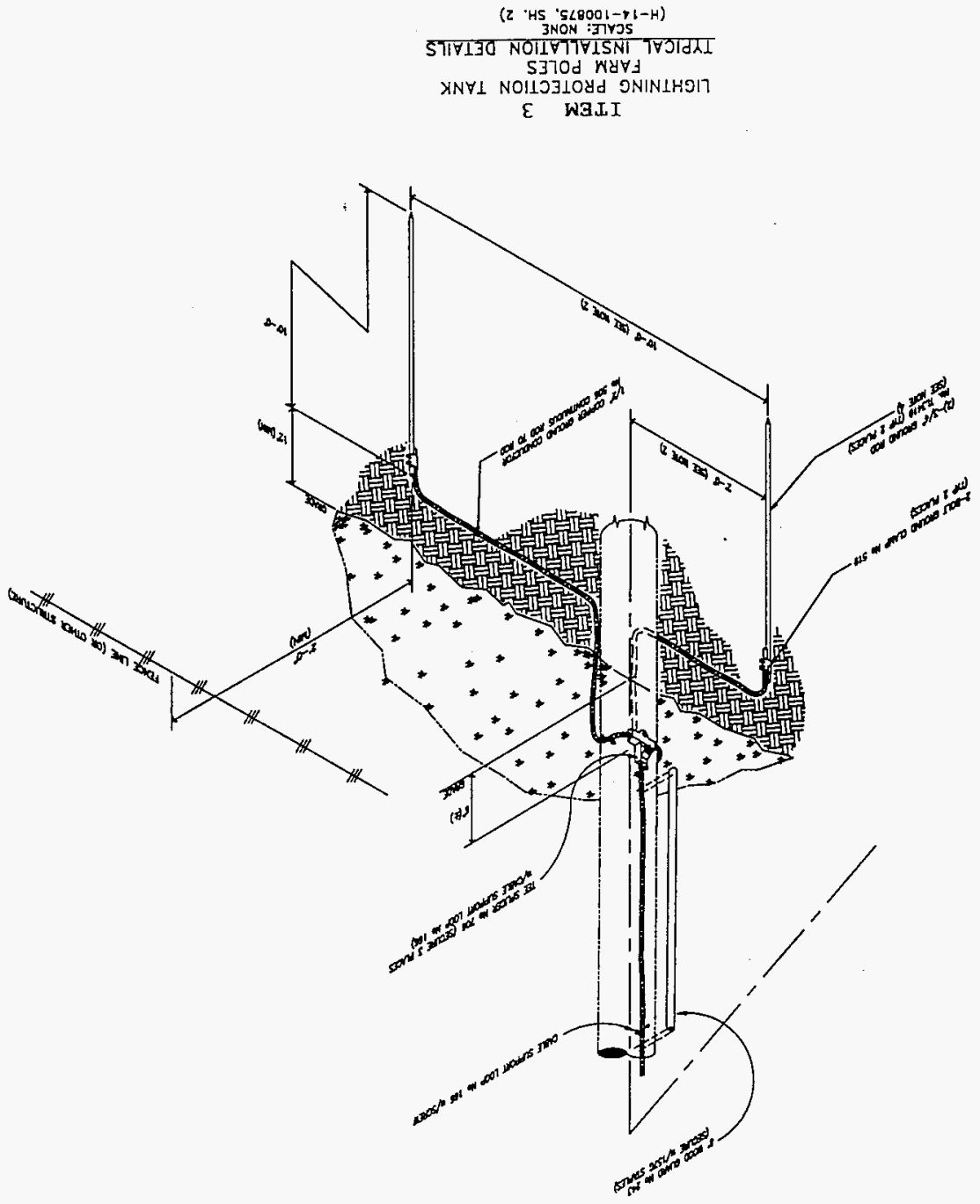


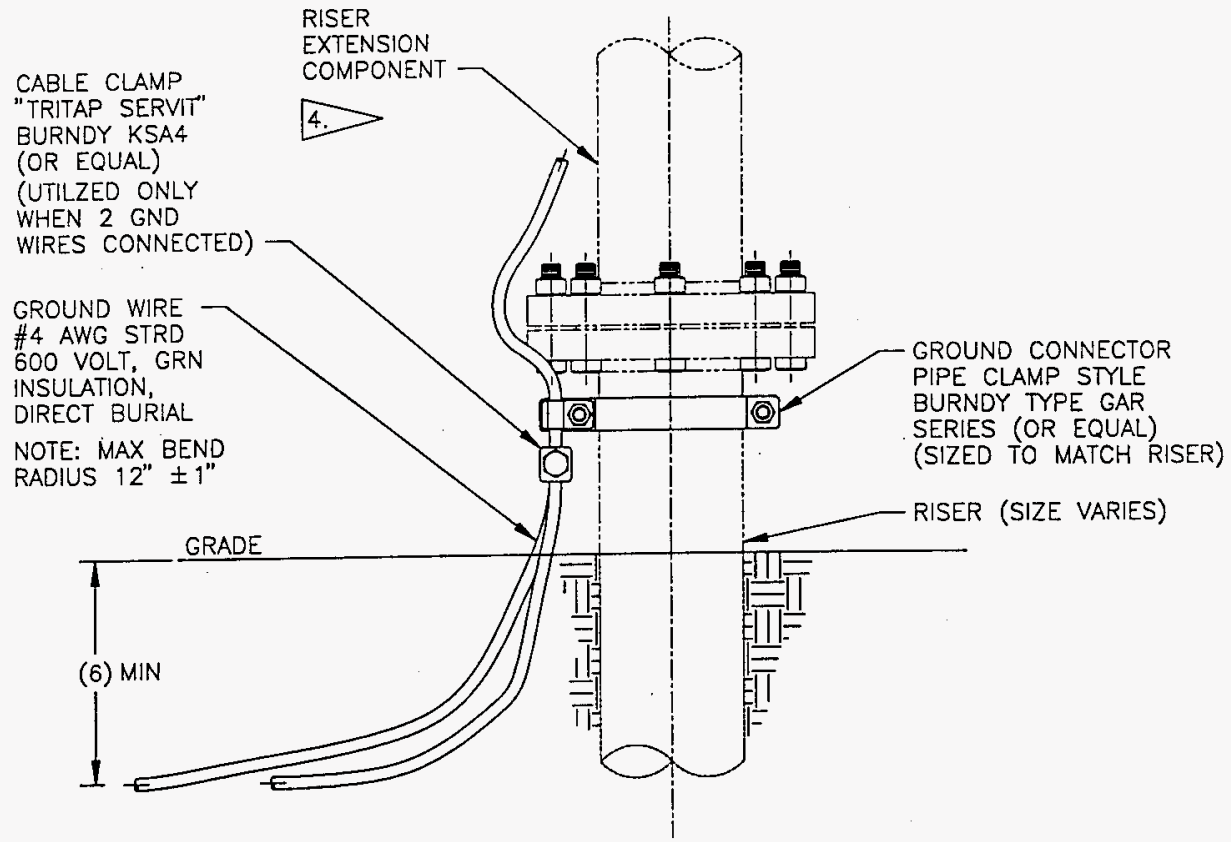

ITEM 4

TYPICAL GROUNDED/BONDED

RISER CONNECTION LINK TO

ANOTHER ACCEPTABLE RISER 


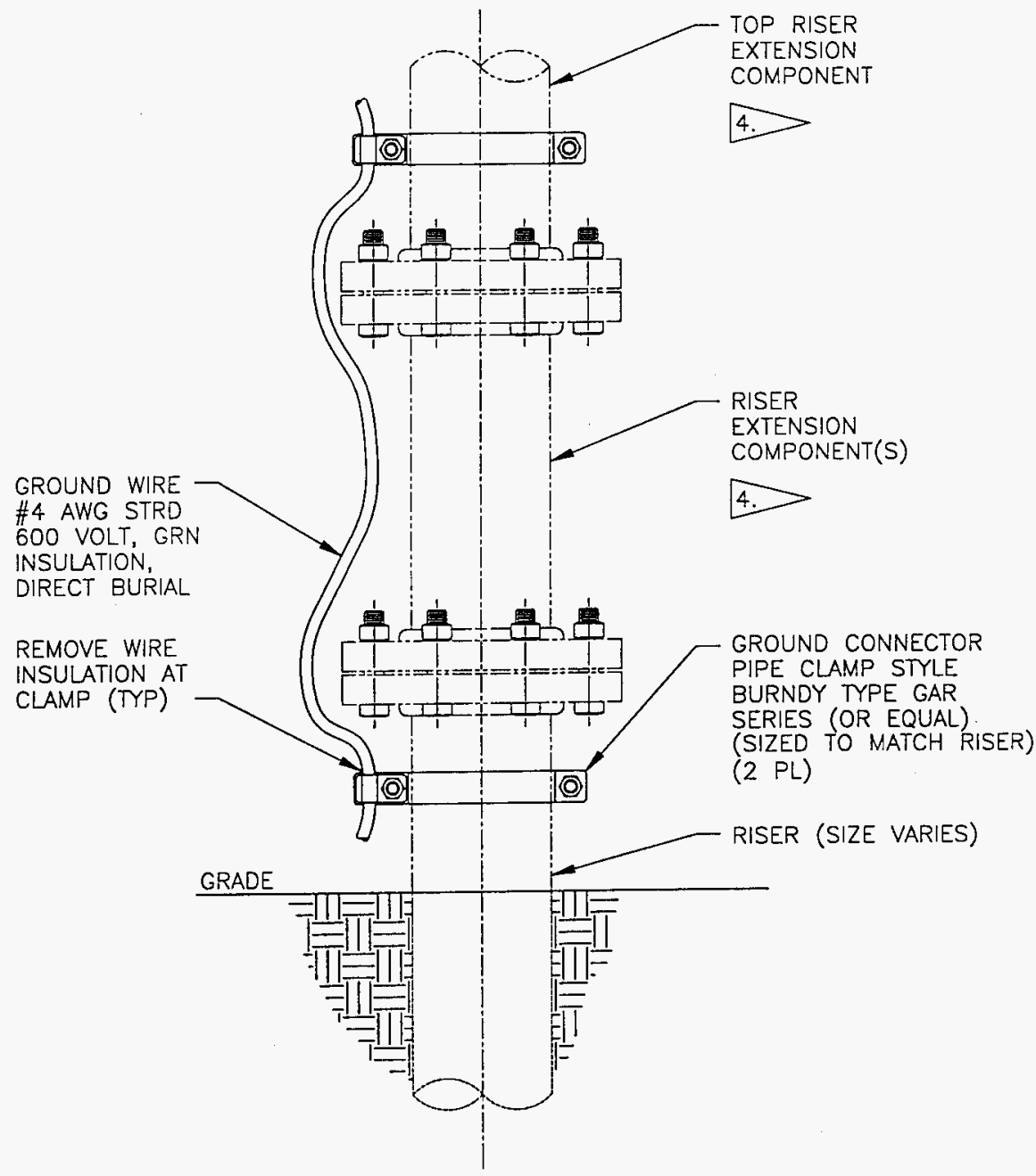

ITEM . 5 .

EXISTING RISER BONDING SCHEME 
HNF-SD-WM-WP-339; Rev. 0

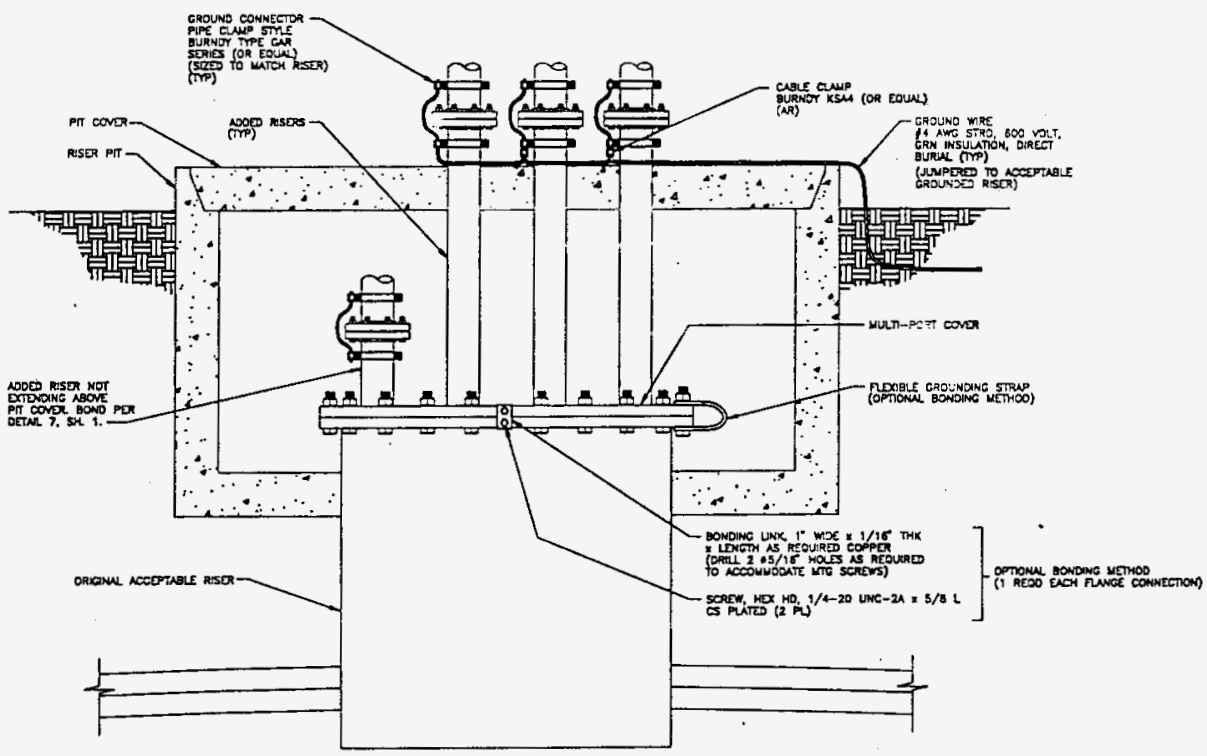

ITEM 7.

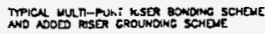




\section{CORRESPONDENCE DISTRIBUTION COVERSHEET}

Author

F. M. Jones

$373-1269$
Addressee

Distribution
Correspondence No.

EDT-156649

Subject: ENGINEERING WORK PLAN TANK FARM LIGHTNING MITIGATION SYSTEM

\section{INTERNAL DISTRIBUTION}

\begin{tabular}{|c|c|c|c|c|}
\hline \multirow[t]{10}{*}{ Aporoval } & Date & Name & Location & w/at \\
\hline & & W. H. Bryant & So-09 & $x$ \\
\hline & & D. W. Crass & $H 5-68$ & $x$ \\
\hline & & F. M. Jones & $\mathrm{H} 6-11$ & $x$ \\
\hline & & J. E. Meacham & $57-14$ & $x$ \\
\hline & & T. L. Ostrander & $53-10$ & $X$ \\
\hline & & R. S. Rodriquez & SO-09 & $x$ \\
\hline & & C. A. Sams & $S 5-12$ & $x$ \\
\hline & & C. C. Scaief III & $R 1-56$ & $x$ \\
\hline & & Central Files & A3-88 & $x$ \\
\hline
\end{tabular}

